\title{
Rota pantanal pacífico - a maior aventura das Américas
}

RESUMO: O que se pretende estudar neste contexto são as possibilidades de consolidação no centrooeste Sul-Americano de uma Rota Turística Internacional sob a ótica do Turismo, da integração e da cultura. Abordamos assim, as possibilidades que essa atividade tem, de exercer seu papel no decorrer da consolidação da rota, como rota turística: Rota Pantanal Pacífico - A Maior Aventura das Américas. Abordamos também o papel da academia, que tem a responsabilidade de gerar conhecimento. Esse projeto nasceu dentro da academia, de um Programa de Pós-Graduação - Mestrado em Geografia/UFMT. A participação que se espera dos governos nesse processo, é a de elaborarem políticas e estratégias de apoio a iniciativa privada, nada mais que isso. $E$ do setor privado, que apoiado pelos governos e pelas informações e estudos gerados nas academias, deve fomentar os investimentos e a construção das estruturas de apoio, e dos produtos turísticos da Rota, gerando a tão esperada integração e desenvolvimento.

ABSTRACT: The aims of these paper is the study of the chances of consolidation in the South American midwest as a International touristic route from the perspective of Tourism, integration and culture. Approach as well, the possibilities that this activity has to exercise its role during the consolidation of tourist route: Pacific Pantanal Route - The Greatest Adventure of the Americas. Approach to the role of the university, which has the responsibility to generate knowledge.This project was born within the academy, a Post-Graduate Program - Master's degree in Geography I UFMT. The expected is the participation of governments in this process to develop policies and strategies to support private sector, nothing more. And the private sector, supported by the governments and information and studies generated by the academies, to encourage investment and construction of support structures, and the tourism products of the route, creating a long-awaited integration and development.

\section{Luiz da Rosa Garcia Netto* \\ Patrícia Helena Mirandola- Avelino*}

*Professores Doutores da Universidade Federal do Mato Grosso, líder do GEEPI Grupo de Estudos Estratégicos e Planejamento Integrado (UFMT \& CNPq) e membro do DIGEAGEO Diretrizes de Gestão Ambiental com uso de Geotecnologias (UFMS \&CNPq)

Palavras-chave: Rota Pantanal Pacífico, Turismo, desenvolvimento

Key-words: Pantanal Pacific Route, Tourism, Development 


\section{Introdução}

Nas últimas décadas, já houve várias as tentativas de integração dos países SulAmericanos, sem um sucesso digamos, consolidado. Assim surge o MERCOSUL, O CONE SUL, a União dos Países da Amazônia, a OTCA - Organização do Tratado de Cooperação Amazônica, o CAF - Confederação Andina de Fomento, CAN Comunidades Andinas, IIRSA -, e outras iniciativas para a Integração da Infra-estrutura da América do Sul, ALCA - Área de Livre Comércio Sul Americana e o MERCOESTE, alguns tem tido sucesso questionável, outros nem isso, pois não se consolidam como integradores de fato.

0 que se pretende estudar neste contexto são as possibilidades de consolidação no centro-oeste Sul-Americano de uma Rota Turística Internacional sob a ótica do turismo, da integração e da cultura, uma vez que, todas as tentativas até agora estudadas e implementadas, objetivando integração, foram basicamente tentadas, sobre a ótica da economia e da logística.

O fato do Brasil, por décadas, ter adotado a política de priorizar acordos comerciais com os países europeus, asiáticos e norte-americanos, impôs à nação certo isolamento, frente aos nossos vizinhos Sul-Americanos. Segundo IPEA (199I), isso sempre dificultou na prática a consolidação dos acordos regionais como: o Tratado de Amizade, Limites, Navegação, Comércio e Extradição (1867), o Tratado de Petrópolis (1903), o Tratado de Natal (1928), o Acordo de Roboré (1958), o Convênio de Transito Livre (1970). Mais recentemente novos Acordos continuam buscando atender ao anseio de integrar os países fronteiriços do Centro Sul Americano, é o caso do Acordo Sobre Transporte Internacional Terrestre - ATITI (de 1990-1995), do Comitê de Fronteiras Cáceres - San Matias (2000), da Reunião Bilateral de Autoridades Aduaneiras Brasil Bolívia - MRE (2006), e da Coleção de Atos Internacionais DAI nº 757.

A integração do espaço regional deve transcender as questões econômicas para englobar questões mais inerentes à qualidade de vida das populações. A intelectualidade do nosso subcontinente deve estar engajada neste processo, com inteligência e mesmo com o sentimento cívico, livre das amarras do próprio sistema, pois o que está em jogo é o desenvolvimento e a autonomia dos países da América do Sul e a dignidade dos seus habitantes. 0 movimento da unidade Sul-Americana deve extrapolar os âmbitos de governos e de negócios para envolver na sua discussão todos os setores sociais - desde os empresariais, os trabalhadores, até os culturais, passando mesmo, pelos militares e acadêmicos.

Como o uso econômico e a conseqüentemente necessidade da alocação de mais recursos, deriva diretamente para o melhor aproveitamento racional do meio-ambiente, os acordos no âmbito da América do Sul, e por que não dizer de Mato Grosso com a Bolívia, deve levar em conta a sustentabilidade e o crescimento da economia a longo-prazo e a distribuição das suas benesses aos povos que habitam a região. Essa questão é essencial no âmbito dos acordos regionais porque representa a superação de conflitos, e evita à queda da qualidade de vida. Então as políticas regionais mais do que coordenadas devem ser planejadas, gerando uma distribuição justa dos investimentos e fomentando a transmissão inter-regional do progresso entre as nações que compõem o Centro-Oeste Sul Americano. Assim, um planejamento de integração deve gerar condições de inserção - a partir das especificidades e heterogeneidades

Geografia Ensino \& Pesquisa, v. 15, n.3, p. 27-54, set./dez. 2011

Rota Pantanal Pacífico - a maior aventura das Américas regionais - produtiva e social, já que esta última é essencial para minorar as desigualdades sociais e se possa alcançar, assim, o objetivo da equidade. Para tanto, o Estado tem um papel importante neste processo, no sentido de tentar manter a identidade nacional. Que impeça que ocorra uma fragmentação do território de grandes dimensões, como o Brasil, por exemplo, quando se definem áreas mais desenvolvidas e outras menos. "Interessante seria se ocorresse 
a tão aspirada integração regional e o incentivo aos mercados, interno e externo fosse considerado, de fato, algo fundamental para o desenvolvimento do país" (Pinto, 2006),

Os estudos e as pesquisas, objetivos desse projeto têm como foco a comprovação de que e eixo Brasil (Mato Grosso), Bolívia, Peru e Chile apresentam condições extremamente favoráveis para a consolidação de uma grande rota de integração cultural, social, ambiental e econômica entre os mesmos, se configurando, nesse sentido, na maior aventura das Américas. A aventura de da integração entre os povos irmãos; $E$, a oportunidade de provar que o mito de que a diferença idiomática é um fator excludente não é verídico, pois, para o Turismo, são justamente nestas diferenças que se caracterizam as potencialidades: as diversidades culturais, ambientais e sociais.

\section{Aspectos Conceituais}

Ao longo dos anos o turismo vem passando por grandes mudanças, desde a sua concepção como atividade econômica até os dias atuais. $\mathrm{O}$ turismo talvez tenha sido a atividade que mais evoluiu nas últimas décadas, pela sua adaptabilidade e flexibilidade. Em decorrência disso, surgiram vários conceitos e pensamentos que em algum momento o denomina de "fenômeno econômico" e em outro de "indústria sem chaminés", ou "indústria verde", e há também aqueles que não concordam com o termo indústria, mesmo que seja a verde, não poluente, ou seja, a atividade turística, seja lá como for chamada, é atualmente uma das maiores fontes geradoras de divisas no mundo. E para conceituá-lo, será estabelecido um debate teórico com autores como Beni (2000), Andrade (1998), Molina (2001), Lemos (2001), Boullón (2002) entre outros.

\section{Turismo - Conceitos}

Para dar início ao entendimento da atividade, Acerenza (1991) sugere que...

muitas vezes a conceituação do turismo tem gerado controvérsias, como conseqüência das múltiplas e variadas interpretações que têm sido feitas dessa disciplina. 0 turismo constitui um campo particular de estudo, ou devido a inúmeros pontos de vista de certas correntes de pensamento que 0 explicam em função dos princípios ideológicos e filósofos que elas professam

O autor acima se refere ao turismo como uma disciplina, admitindo as variáveis em sua concepção. Já Di Beltrão (1999) refere-se ao mesmo como uma atividade....

O turismo é o conjunto de todas as atividades sociais, culturais, políticas, econômicas e naturais que envolvem pessoas se deslocando através dos mais diversos lugares de origem em busca de outros destinos desconhecidos ou não, com uma permanência temporária..

Andrade (1998) conseguiu sintetizar em poucas palavras o turismo com uma visão bem contemporânea do que é a atividade turística, dizendo...

Turismo é o complexo de atividades e serviços relacionados aos deslocamentos, transportes, alojamentos, alimentação, circulação de produtos típicos, atividades relacionadas aos movimentos culturais, visitas, lazer e entretenimento....

Geografia Ensino \& Pesquisa, v. 15, n.3, p. 27-54, set./dez. 2011

Já para Ignarra (1999) apud De La Torre (1992)

Garcia Netto, L. R; Avelino, P. H. M

O turismo é um fenômeno social que consiste no deslocamento voluntário e temporário de indivíduos ou grupos de pessoas que, fundamentalmente 
por motivos de recreação, descanso, cultura ou saúde, saem de seu local de residência habitual para outro, no qual não exercem nenhuma atividade lucrativa nem remunerada, gerando múltiplas inter-relações de importância social, econômica e cultural.

Ocorre aqui uma concordância em parte com esse conceito, mas não em sua totalidade, devido ao fato do autor limitar a atividade turística apenas ao campo da "recreação, descanso, cultura e saúde", deixando de fora inúmeras outras atividades, diretas e indiretas do setor, como: gastronomia, eventos, religiosa, desportiva, ecológica, científica e principalmente pelo fato de não reconhecer como turísticas as atividades econômicas. No entanto, é citado para demonstrar a evolução dos conceitos turísticos que foram mencionados na introdução. Ignarra publicou esse livro no ano de 1.999 e teve sua $2^{\mathrm{a}}$ edição no ano de 2.000 quando citou De la Torre, El Turismo, Fenômeno Social, Cidade do México: Fundo de Cultura Econômico, 1992. E num período de 15 anos, o então falado "fenômeno econômico" vem evoluindo. Di Beltrão (1999) diz que: "turismo envolve todas as atividades sociais, culturais, políticas, econômicas e naturais".

\section{O Produto Turístico}

As várias faces da conceituação turística existem em todos os setores que a compõe, por ser uma atividade nova e principalmente por seu crescimento e seu caráter multifacetado e todas as suas interconexões com os demais setores da economia. 0 turismo consegue se envolver de uma forma dinâmica com os setores primários, secundários e se consolida de fato como um segmento no setor terciário. Por isso, a definição de seus produtos e serviços são também múltiplos e diferentes e, no entanto, se relacionam Boullón (2002)

Embora seja verdade que, do ponto de vista econômico, a oferta turística não pode ser outra coisa senão um bem ou um serviço, traduzir textualmente esse conceito leva-nos a deduzir que o produto turístico é formado pelos mesmos bens e serviços que fazem parte da oferta. No que diz respeito aos bens, já foi esclarecido que são comercializados pelo turismo, sem que haja qualquer bem de consumo que se originem em um aparelho produtivo exclusivamente turístico. Quanto aos serviços, efetivamente integram o produto turístico, mas não são os únicos nem os mais importantes componentes, por que, na realidade, os serviços são mais um meio do que o fim: o fim é a prática das atividades turísticas...

Já Andrade (1998) traz outra visão a respeito de produto-oferta turística que de fato é bastante pertinente à visão dessa pesquisa ao dizer da relação que o turismo tem ou cria com os setores da economia

O produto turístico é um conjunto de bens e serviços diversificados e essencialmente relacionados entre si, tanto em razão de sua integração com vistas ao atendimento da demanda quanto pelo fator de unir os setores primário, secundário e terciário de produção econômica..

Geografia Ensino \& Pesquisa, v. 15, n.3, p. 27-54 set./dez. 2011

Rota Pantanal Pacífico - a maior aventura das Américas

\section{Definição de Mercado Turístico}

$O$ produto da relação entre a produção e o consumo gera um setor dinâmico de interrelações que é chamado de mercado. Nesse caso, constitui-se no mercado turístico, onde os produtos são criados, formatados e ordenados para serem disponibilizados como produtos turísticos prontos para a promoção e comercialização. Lage \& Milone (2000) trazem uma definição bastante ampla como conceito que atende à visão implícita neste trabalho, 
especialmente ao citar o turismo de evento que é mercado em extrema ascensão dentro do país, bem como do continente, devido ao desenvolvimento econômico dos países Sul Americanos. E isso empresta uma contribuição significativa a este setor específico do turismo, onde ambos se fortalecem...

Chamamos de mercado turístico a interação da demanda de produtos relacionados com a execução e operacionalização das atividades que envolvem bens e serviços de viagens e afins. Esse mercado pode ser considerado como uma vasta rede de informações de modo que os agentes econômicos - consumidores e produtores - troquem informações e tomem decisões sobre a compra e a venda dos diferentes bens e serviços a sua disposição. A linguagem ou a forma de comunicação que estes agentes no turismo usam para o entendimento é feita pôr meio dos preços e de seus bens, que se constituem no principal mecanismo de todo o sistema de mercado. 0 turismo de eventos é à parte do turismo que leva em consideração o critério relacionado ao objetivo da atividade turística, É praticado com interesse profissional através de congressos, convenções, simpósios, feiras, encontros culturais, reuniões internacionais, entre outros, e é uma das atividades econômicas que mais crescem no mundo atual.

Ansarah (1999) conseguiu reunir vários autores e lançou o livro "TURISMO: Segmentação de Mercado", apresentando uma coletânea de autores que segmentam e definem muito bem 0 mercado turístico. Nessa abordagem sobre a segmentação do mercado turístico, adotamos estrategicamente três conceitos, ou melhor, três definições de mercado turístico, os quais vêm de encontro com a proposta deste trabalho, pois abordam a problemática do planejamento de longo prazo e sugerem algumas ações que poderão contribuir com desenvolvimento turístico, regional, nacional e internacional.

Outro mercado turístico em potencial a ser explorado e ofertado dentro dos padrões de desenvolvimento local, municipal, microrregional e estadual é o mercado do agroturismo, com a proposta de abranger extensas áreas produtivas, essencialmente em território mato-grossense, um dos maiores na produção agro-industrial brasileira, por sua localização geográfica, pela qualidade de seus solos e favorabilidade climática, fazendo do Estado um referencial do agronegócio brasileiro, favorecendo dessa forma o desenvolvimento de atividades turísticas no meio rural. 0 agroturismo é entendido

\begin{abstract}
... como a modalidade de turismo em espaço rural praticada dentro das propriedades, de modo que o turista e/ou excursionista entra, mesmo que pôr curto período de tempo, em contato com a atmosfera da vida na fazenda, integrando-se de alguma forma aos hábitos locais. Tal distinção faz-se necessária, uma vez que se pode, por exemplo, praticar o turismo ambiental em espaço rural, ou seja, não especificamente no interior de uma propriedade. (PORTUGUEZ, 1999).
\end{abstract}

\section{Definição de Planejamento Turístico}

O planejamento faz parte de tudo que se pretende realizar, organizar, promover, criar, enfim, está implícito em todas as atividades humanas.

Ignarra (1999), apud Muñoz (1996), em seu livro Fundamentos do Turismo, conseguiu conceituar da melhor maneira possível o processo de planejar, dizendo que

O planejamento consiste na definição dos objetivos, na ordenação dos recursos materiais e humanos, na determinação dos métodos e formas de organização,

Geografia Ensino \& Pesquisa, v. 15, n.3, p. $27-54$, set./dez. 2011

Garcia Netto, L. R; Avelino, P. H. M

ISSN 2236- 4994 
no estabelecimento das medidas de tempo, quantidade e qualidade, na localização espacial das atividades e outras especificações necessárias para canalizar racionalmente a conduta de uma pessoa ou grupo

Já Ruschmann (2000), entende como a melhor definição de planejamento o conceito de Estol \& Albuquerque ao dizer que uma das melhores formas para abranger o planejamento é aquela que 0 entende como

... um processo que consiste em determinar os objetivos de trabalho, ordenar os recursos materiais e humanos disponiveis os métodos e as técnicas aplicáveis, estabelecer as formas de organização e expor com precisão todas as especificações necessárias para que a conduta da pessoa ou do grupo de pessoas que atuarão na execução dos trabalhos seja racionalmente direcionada para alcançar os resultados pretendidos.

Existem inúmeros conceitos de planejamento, devido ao fato de ser algo primordial em todas as áreas, em todos os segmentos e atividades. Uma das melhores definições de conceito de planejamento já encontrado foi o de Bissoli (1999), ao afirmar que

O planejamento turístico é um processo que analisa a atividade turística de um determinado espaço geográfico, diagnosticando seu desenvolvimento e fixando um modelo de atuação mediante 0 estabelecimento de metas, objetivos, estratégias e diretrizes com os quais se pretende impulsionar, coordenar e integrar o turismo ao conjunto macroeconômico em que está inserido. Deve se entender como uma ação social, no sentido de que vai ser dirigido à comunidade, e racional, na medida em que é um processo que tende a estabelecer uma série de decisões com um alto grau de racionalização.

Quando se pensa em planejar o turismo é necessário pensar nas várias fases do planejamento, na sua aplicabilidade, sua viabilidade econômica, social e cultural, na sua importância e relevância para a base local, na sua abrangência e tempo, ou seja, delimitar todas as características desse planejamento. A proposta é basicamente chegar a um modelo de planejamento adequado para o desenvolvimento regional de uma forma estratégica, partindo do todo para o local, cabendo então demonstrar-lhes quais são essas modalidades de planejamento e qual será sugerida neste trabalho como proposta para o Centro Oeste Sul Americano. Beni (2000) nos diz que o planejamento regional do turismo

É um conjunto de pólos de desenvolvimento turístico hierarquizados, unidos por uma infra-estrutura comum que, em sua totalidade, contribuem para dinamizar o desenvolvimento econômico e social de extensas partes (...). 0 setor de turismo, que precisa ser sempre expressado e representado em sua complexa totalidade, demanda um tipo de planejamento a que se agrega a palavra integrado, indicando, com isso, que todos os seus componentes devem estar devidamente sincronizados e seqüencialmente ajustados, a fim de produzir o atingimento das metas e diretrizes da área de atuação de cada um dos componentes a um só tempo, para que o sistema global possa ser implementado e imediatamente passar a ofertar

Geografia Ensino \& Pesquisa, v. 15, n.3, p. 27-54, set./dez. 2011

Rota Pantanal Pacífico - a maior aventura das Américas oportunidades de pronto acompanhamento, avaliação e revisão.

O autor conseguiu em poucas linhas traduzir tudo aquilo que será proposto como modelo de desenvolvimento turístico. Acredita-se que o planejamento meso-regional e microrregional seja o modelo mais viável para a região de estudo, tendo em vista sua extensão territorial que 
atinge dimensões continentais, o que acaba por estrangular a si mesmo quando se pensa em planejá-lo integralmente.

Para Boullón (2002)...

Uma das condições que o planejamento regional deve cumprir é que as partes das quais se ocupa abranjam todo território do país. A segunda exigência é que cada região abranja uma superfície que tenha propriedades iguais. Como é impossível dividir, fisicamente, um país em áreas nas quais cada metro seja idêntico ao resto, à idéia de região que os economistas utilizam refere-se às porções do território cujos indicadores econômicos (a produção, o transporte, o comércio etc.) e de desenvolvimento social (a alfabetização, a moradia, a saúde, os salários etc.) são similares.

A visão dos autores no que se refere ao planejamento, bem como na concepção das áreas a serem planejadas, atende e se aplica plenamente à visão e à proposta da Rota, pois a mesma está constituída por partes iguais de territórios dos países que a compõe, dando desta maneira o caráter de itinerário contínuo, interligados por atrativos naturais e culturais e pela logística dos serviços que a torna viável. Assim como acrescenta Ferraz (1992)

O momento inicial da atividade econômica do turismo é a existência de atrativos naturais e culturais que despertem interesse de visitação. Compõem o chamado patrimônio turístico. Propiciar essa visitação é a função da estrutura de produção de serviços de transporte, alojamento, alimentação, entretenimento, agenciamento e outros. Adequar à estrutura de produção implica normatizar o padrão de qualidade de seus serviços, a fim de propiciar o incremento do consumo, que realimenta todo o ciclo. Assim, a intervenção estatal pode indicar na ordenação do patrimônio turístico, no apoio à produção, no controle de qualidade do produto e no incentivo do consumo.

Beni (2000) e Ferraz (1992) apontaram um modelo de planejamento e uma ação planejadora, quando se identifica o patrimônio turístico de uma localidade é necessário planejála, ordená-la, incrementá-la, ou seja, transformá-la em produto. E, encontrar a forma para esse processo é função do planejamento e neste caso será função do planejamento meso e microrregional estratégico. Rasmussen (1990) define muito bem ao dizer que 0

Planejamento estratégico, por definição, significa planejar o futuro perante as limitações psicológicas e físicas e os pontos fortes e fracos de uma organização, considerando as alterações do comportamento do macro ambiente referente aos segmentos econômicos, políticos, tecnológicos, sociais, legais, geográficos, demográficos e principalmente, competitivos.

Para que esse planejamento estratégico realmente alcance a ordenação adequada de todos os recursos envolvidos será preciso estar intrínseco em sua metodologia a sustentabilidade. Na mais abrangente forma possível, como a sustentabilidade do espaço, da sociedade, da economia e, é claro, dos recursos naturais. Oliveira (2000) nos traz alguns conceitos de sustentabilidade que nos dão uma dimensão do ideal sustentável. Para ele a

Sustentabilidade espacial baseia-se na distribuição geográfica mais equilibrada dos assentamentos turísticos para evitar a super-concentração de pessoas, de equipamentos e de infra-estrutura turística e, conseqüentemente, diminuir a destruição de ecossistemas frágeis e a deterioração da qualidade da experiência do turista.

Geografia Ensino \& Pesquisa, v. 15, n.3, p. 27-54, set./dez. 2011

Garcia Netto, L. R; Avelino, P. H. M 
*Imperativo. É aquele cujos delineamentos poder ser aceitos pôr todas as pessoas físicas e morais que se relacionam com 0 fenômeno que se pretende modificar. Sua observância é obrigatória, e geralmente acontece em países com governo totalitário.

Indicativo. Contrariamente ao anterior, sua observância é facultativa, uma vez que os delineamentos são tomados como sugestão do setor público sobre o que se deve fazer. Sua função e exclusivamente orientar.
Já a sustentabilidade social é entendida pelo autor como uma prática...

... fundamentada no estabelecimento que conduza a um padrão de crescimento, com uma distribuição mais eqüitativa de renda, redução das atuais diferenças sociais e a garantia dos diretos da cidadania....sustentabilidade econômica é algo que assegure o crescimento econômico para as gerações atuais e, ao mesmo tempo, o manejo responsável dos recursos naturais, que deverão satisfazer as necessidades das gerações futuras..

Essa visão abordada pelo autor onde os recursos naturais satisfarão as necessidades futuras é algo importante, pois, abordar a sustentabilidade econômica pautada da manutenção dos recursos naturais é uma questão óbvia. Norton (1992) apud Faria (2001) conseguiu formular um dos mais completos conceitos de sustentabilidade, ao dizer que...

Sustentabilidade é uma relação entre sistemas econômicos dinâmicos e sistemas ecológicos maiores, também dinâmicos e que, no entanto, modificam-se mais lentamente, de tal forma que a vida humana pode continuar indefinidamente, os indivíduos podem prosperar e as culturas humanas podem desenvolver-se - mas, também, uma relação na qual os efeitos das atividades humanas permanecem dentro de limites que não deterioram a saúde e a integridade de sistemas auto-organizados que fornecem o contexto ambiental para estas atividades.

Dentro da abordagem turística, nota-se claramente a existência de um tripé que movimenta tal segmento: economia, ecologia e sociedade. Quando se fala em sustentabilidade, em processos de desenvolvimento, sejam eles turísticos ou não, estarão sempre gerando interferências econômicas em bases ecológicas, ou vice-versa, o que resultará num conceito cultural de sociedade. E em meio a esse tripé é que surge a discussão sobre a sustentabilidade, mais precisamente a ecológica. Podem existir culturas e sociedades que de forma natural adotam procedimentos voltados a ações preservacionistas e outras que são embasadas meramente por interesses econômicos.

Faria (2001) aborda outro ponto de vista conceitual ao citar Holling (1993) a respeito da sustentabilidade ecológica, e diz que...

Existe uma imprevisibilidade inerente ao desenvolvimento sustentável resultante do desconhecimento e da imprevisibilidade inerente à evolução de sistemas manejados e às sociedades às quais eles estão ligados. 0 ponto essencial é que a evolução de sistemas requer políticas e ações que não apenas satisfaçam os objetivos sociais, mas que, ao mesmo tempo, atinjam continuamente 0 entendimento das condições de evolução e forneçam flexibilidade para a adaptação às surpresas

Este modo de expor é reconhecido no planejamento estratégico e integral, segundo Molina (2001) ao dizer que "Basicamente a metodologia integral de planejamento deve considerar a análise de uma série de variáveis que condicionam o modo e o nível de vida do grupo humano", e misto, e o regional "válido para uma grande região (...) com características físicas, econômicas e sociais semelhantes", dentro desse modelo de planejamento regional pode se acrescentar em suas características às semelhanças ecológico-ambientais. E finalizando, o global que, "abarca com suas linhas toda uma nação e seus diferentes setores".

Esse tipo de planejamento não é realmente uma modalidade, mas uma combinação dos anteriores * um mesmo âmbito espaço-temporal. Desta 
maneira, sua observância é obrigatória na esfera pública, e facultativa para dos demais setores (privado e social). Este tipo de planejamento é muito comum na América Latina, devido à natureza desenvolvimentista de grandes partes de seus governos.

O planejamento pela sua essencialidade em tudo que promove é algo que gera várias modalidades e diferentes conceitos, e a respeito disso poderiam ser demonstrados pensamentos e teorias distintas de planejamento especialmente por se tratar de desenvolvimento sustentável. Já que para essa proposta os dois são indissociáveis, para finalizar a definição de planejamento turístico e o mesmo com ações sustentáveis, vale citar um método apresentado por Boullón (2002), na realidade uma característica, que nesse caso funciona como uma sugestão metodológica.

O planejamento físico é uma técnica que pertence às categorias experimentais do conhecimento científico. Sua finalidade é 0 ordenamento das ações do homem sobre o território, e ocupa-se em resolver harmonicamente a construção de todo tipo de coisas, bem como em antecipar o efeito da exploração dos recursos naturais.

Vale considerar que a atividade turística processa basicamente duas matérias primas: os recursos naturais e culturais, formatando-as e ofertando-as como produtos no mercado turístico como condicionantes do desenvolvimento da atividade.

\section{Turismo e Cultura}

Laraia (1997) traz em seu livro "Cultura um conceito antropológico" em sua $11^{\text {a }}$ edição, alguns conceitos que servem de base na relação entre turismo e cultura. Assim, como se busca entender o conceito de turismo através de várias linhas e apontar as diferenças conceituais entre as escolas bem como seus pensadores, apresenta algumas definições de cultura.

A primeira definição de cultura que foi formulada do ponto de vista antropológico, como está, no primeiro parágrafo do livro Primitive Culture (Tylor, 1871), procurou, demonstrar que cultura pode ser objeto de um estudo sistemático, pois se trata de um fenômeno natural que possui causas e regularidades, permitindo um estudo objetivo e uma análise capaz de proporcionar a formulação de leis, o processo cultural e a evolução.

Ainda em Laraia (1997) pode-se encontrar no $6^{\circ}$ capítulo de seu livro que trata das "teorias modernas sobre cultura", algumas definições em seu artigo 'Theories of Culture', entendendo a cultura como

\begin{abstract}
...culturas são sistemas (de padrões e comportamentos socialmente transmitidos) que servem para adaptar as comunidades humanas aos seus embasamentos biológicos. Esse modo de vida as comunidades inclui tecnologias e modos de organização econômica, padrões de estabelecimento, de agrupamento social e organização política, crenças e práticas religiosas, e assim por diante.
\end{abstract}

E no universo turístico com todos seus afins, diretos, indiretos e de interesse, a cultura é algo que influi fortemente na geração dos deslocamentos e na prestação de serviços que acabam ocasionando o surgimento do turismo. Ou seja, o turismo tem uma forte ligação com a cultura e vice-versa, pelo simples fato de que tudo o que uma determinada população produz, retrata a sua cultura, a peculiaridade, a singularidade que pertence a esse povo, formando assim sua cultura. Para o turismo, a cultura é um dos fatores que o viabiliza.
Geografia Ensino \& Pesquisa, v. 15, n.3, p. 27-54, set./dez. 2011

Garcia Netto, L. R; Avelino, P. H. M 
Assim, a mesma motivou os primeiros viajantes em suas cruzadas nos primórdios dos tempos, em busca de novas culturas, novas raças, novas descobertas e conquistas, impulsionados pela própria cultura. E até hoje continuamos a seguir nossos instintos culturais em busca do novo, do lúdico, do sagrado, do diferente. Por esses motivos, a cultura constitui uma das bases estruturais do turismo

\begin{abstract}
A cultura, tal quais os cientistas sociais a concebem, refere-se ao modo de vida de um povo, em volta a sua extensão e complexidade. Um conceito que procura designar uma estrutura social no campo das idéias, das crenças, costumes, artes, linguagem, moral, direito, leis, etc., e que se traduz nas formas de agir, sentir e pensar de uma coletividade que aprende, inova e renova o seu próprio modo de criar e fazer as coisas, numa dinâmica de constantes transformações. A cultura pode, portanto, a partir deste ponto de vista, ser entendida como manifestações espontâneas de um determinado grupo social que, uma vez incorporadas ao seu 'modus vivendi', o caracteriza e o distingue dos demais.
\end{abstract}

De acordo com a definição acima, de Muylaert (1995), podemos afirmar que: a cultura molda, define e constrói as características do mercado, da demanda e do produto turístico, confirmando dessa forma que a cultura embasa o turismo. 0 mercado turístico mato-grossense, por exemplo, difere do mercado turístico "cruceño", que por sua vez difere do "cusqueño", ou "atacameño", que, no entanto, é diferente de qualquer outro mercado devido às suas peculiaridades representadas pela cultura local.

Mesmo os atrativos naturais serão da mesma forma, diferentes, não apenas pelas mudanças naturais, como a ação do vento, da chuva, do sol e tantos outros elementos que os distinguem, mas, principalmente, devido à ação do homem exercida basicamente por sua cultura que ali deixou as marcas de sua forma de agir. $\mathrm{O}$ homem modifica tudo aquilo que toca, harmoniosamente ou não, e sempre de acordo com seus valores. E essas diferenças geram atrativos, que geram os deslocamentos, que geram as prestações de serviços e que por fim geram o turismo "quanto à subjetividade, a troca de vivências entre diferentes culturas é fonte riquíssima e inesgotável de aprendizagem. É o ponto através do qual o viajante pode voltar a ter, em suas andanças, retorno em crescimento individual" (LEMOS 2001).

\title{
Metodologia de Trabalho
}

Geografia Ensino \& Pesquisa, v. 15, n.3, p. 27-54, set./dez. 2011

Rota Pantanal Pacífico - a maior aventura das Américas

O Objetivo Geral dessa proposta se configura no LEVANTAMENTO E ANÁLISE DAS POTENCIALIDADES TURÍSTICAS, AMBIENTAIS E SÓCIO-ECONÔMICAS COM VISTAS À MELHOR INTEGRAÇÃO ENTRE BRASIL, BOLÍVIA, PERU E CHILE, através do Turismo; à melhor compreensão do processo de integração dos setores sociais e políticos; análise da infraestrutura e do transporte, sob a ótica do Turismo. E, principalmente, confirmar que o eixo entre 0 Pantanal e o Pacífico, de aproximadamente $4.500 \mathrm{~km}$, por nós denominado doravante Rota Pantanal-Pacífico, pode se configurar na maior aventura das Américas, e num vetor da melhoria das relações existentes entre os países pelos quais passa (figura 01). Aliás, esse foi o objeto da Dissertação de Mestrado, no Programa de Pós-Graduação em Geografia da UFMT, da Turismóloga Vanilde Alves de Carvalho, primeira Diretora do IPP - Instituto Pantanal Pacífico.

Assim, foi objeto específico do trabalho, levantar as condições ambientais, geográficas, físicas e humanas do entorno do eixo. Este projeto vem se desenvolvendo com apoio 
acadêmico e equipamentos dos Departamentos de Geografia da UFMT e do Laboratório de Geoprocessamento do DIGEAGEO e o importante apoio financeiro da FAPEMAT - Fundação de Amparo à Pesquisa de Mato Grosso.

Os dados, informações e materiais levantados possibilitaram a idealização de sugestões seguras, de quais atividades se poderão desenvolver ou agregar ; O que será possível promover em prol da melhor integração entre os países ; $E$ as possibilidades do envolvimento dos grupos residentes locais no processo, que leve a melhoria na qualidade de vida das comunidades existentes ao longo das estradas que ligam o Pantanal Brasileiro ao Pacífico chileno.

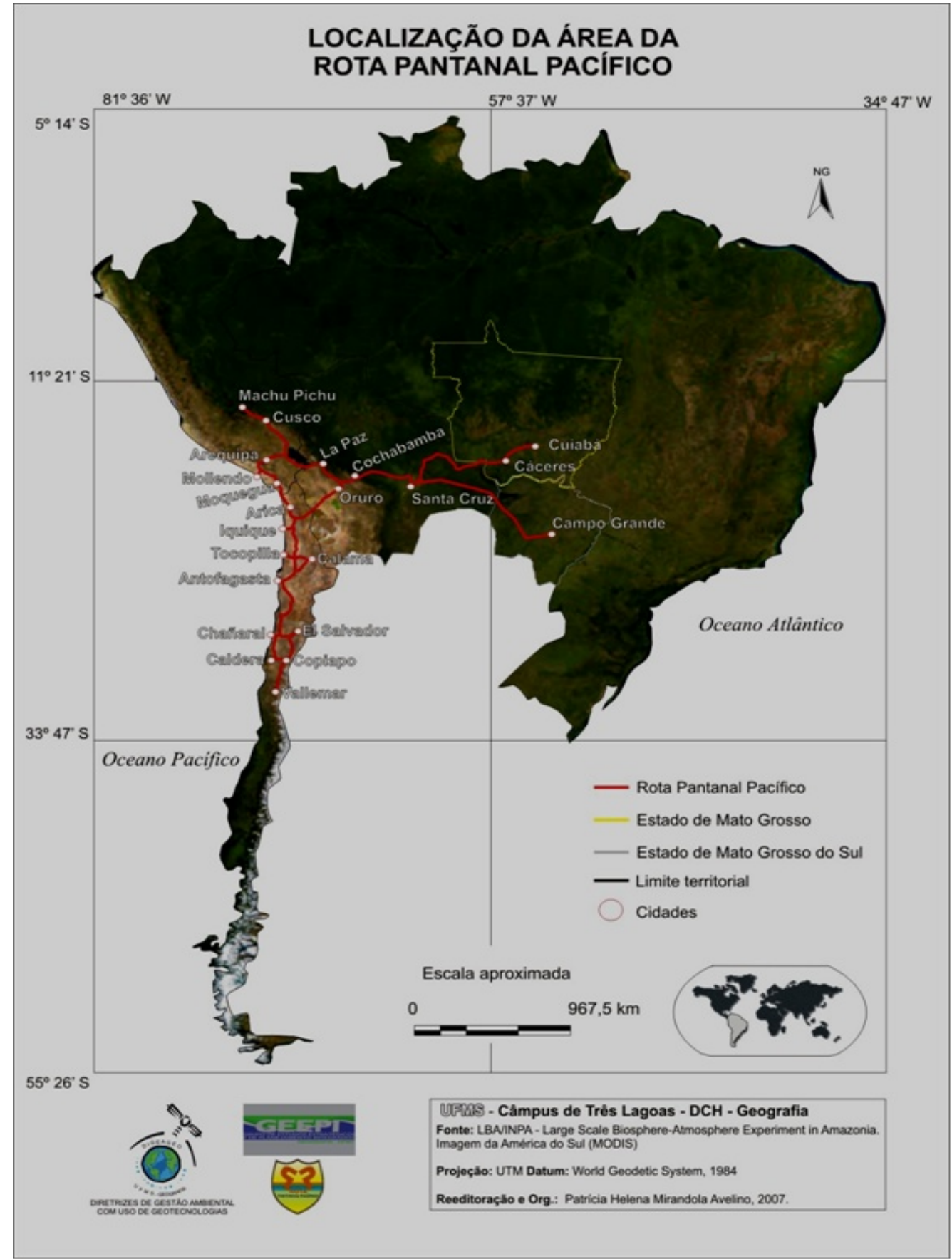

Figura 01- Apresenta em detalhe a Rota da 1ª . Expedição que partiu de Cuiabá/MT. E, a Rota da 2a . Expedição - Projeto em parceria com DIGEAGEO/UFMS, que parte de Campo Grande/MS.
Geografia Ensino \& Pesquisa, v. 15, n.3, p. 27-54, set./dez. 2011

Garcia Netto, L. R; Avelino, P. H. M 
Para tanto, já executamos a 1á. Expedição Cientíica, de 26 dias, em julho de 2007, com apoio da FAPEMAT. Neste caso o projeto foi submetido a Edital, que aprovou um recurso na ordem de $\mathrm{R} \$ 50.000,00$.

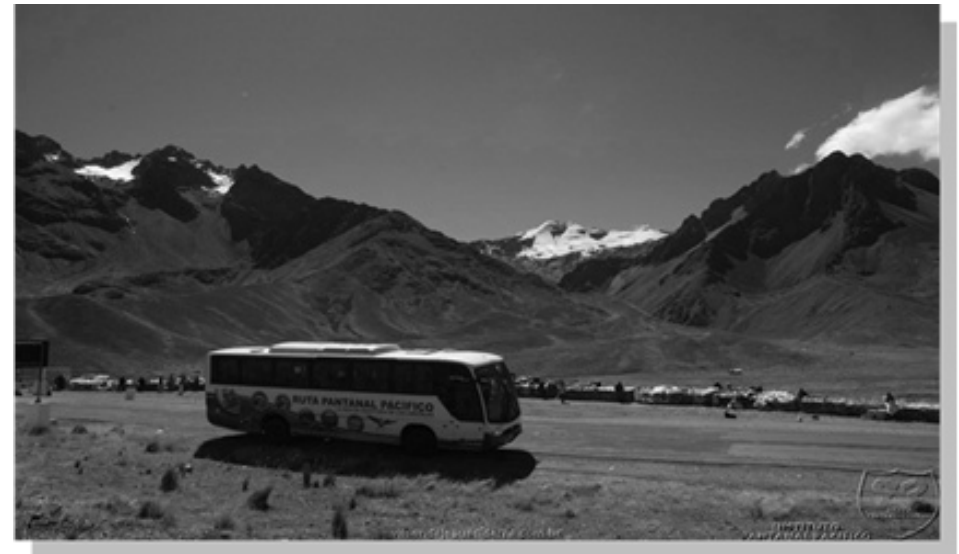

Figura 02- Cena do ônibus durante a $1^{\text {a }}$. Expedição já na região dos Andes peruanos, próximo de Arequipa. (foto: Vilson de Jesus).

Este financiamento possibilitou a coleta de dados e informações relativos aos aspectos fisiográficos, humanos com potencialidade turística ao longo do trecho da rota e entorno. 0 trecho executado teve seu início em Cuiabá, saindo do Brasil por Cáceres. Esta expedição foi coordenada pelo GEEPI - Grupo de Estudos Estratégicos e de Planejamento Integrados, com apoio do PPGGeo/UFMT e DIGEAGEO/UFMS.

Está em fase de elaboração de projeto Uma Proposta de Execução da 2a. Expedição Científica, que será Coordenado pelo Grupo de Estudos DIGEAGEO - Diretrizes de Gestão Ambiental com uso de Geotecnologias/Depto de Geografia/Campus Três Lagoas/UFMS, que tem mais ou menos os mesmos objetivos da 1 1ª Expedição, mas com diferenças básicas, (1) do envolvimento da UFMS e do estado de Mato Grosso do Sul na proposta. (2) 0 roteiro muda também, com a saída de Campo Grande, via Corumbá, com (3) proposta de inserção/utilização do trem como transporte alternativo, até Santa Cruz de La Sierra. E, o estudo da possibilidade de uso do trem em outros trechos na Bolívia, Perú e Chile, cuja infra-estrutura já existe, mas que hoje só transporta carga.

É foco de estudo também, analisar se essa nova proposta de consolidação do turismo como atividade econômica de apoio, tem condições de ajudar a impulsionar os avanços, rumo à maior integração da comunidade Sul - Americana. 


\begin{tabular}{|c|c|c|}
\hline Coordenador & \multicolumn{2}{|l|}{ Luiz da Rosa Garcia Netto } \\
\hline Instituição Executora & \multicolumn{2}{|c|}{$\begin{array}{c}\text { GEEPI - Grupo de Estudos Estratégicos e de Planejamento Integrados } \\
\text { DIGEAGEO - Diretrizes de Gestão Ambiental com Uso de } \\
\text { Geotecnologias/UFMS }\end{array}$} \\
\hline $\begin{array}{l}\text { Outras Instituições envolvidas no } \\
\text { projeto }\end{array}$ & \multicolumn{2}{|l|}{$\begin{array}{l}\text { AMM - Associação Matogrossense dos Municípios } \\
\text { UFMS - Universidade Federal de Mato Grosso do Sul }\end{array}$} \\
\hline \multirow{9}{*}{ Equipe Executora } & Nome do Pesquisador & Instituição \\
\hline & 1 - Luiz da Rosa Garcia Netto & UFMT \\
\hline & 2 - Vanilde Alves de Carvalho & UFMT \\
\hline & 3 - Ivanisa de L. Lazzarotto Cabral & UFMT \\
\hline & 4 - Francisco Cunha Lacerda & AMM \\
\hline & 5 - Patricia Helena Avelino Mirandola (Líder DIGEAGEO) & UFMS \\
\hline & 6 - Giseli Dalla Nora Felix & UFMT \\
\hline & 7 - Vilson de Jesus & AL/MT \\
\hline & Alunos matriculados nas disciplinas (10) & UFMT \\
\hline
\end{tabular}

\section{Potencial dos Eventos Cênicos}

Qualquer ação que se passa dentro do âmbito de visão do observador tem um significado que nos proporciona os mais distintos olhares e as mais variadas contemplações. Perspectiva panorâmica, espetáculo, cenário, palco, seja lá qual for o adjetivo, todos levam a identificação das particularidades que constituem as paisagens geográficas. No presente trabalho isso se materializou com a coletânea de farto material fotográfico, que resultará num banco de imagens (em execução), além de filmagens e registros dos relatos da população local.

Sendo assim, para uma melhor explanação dos acontecimentos e dos próprios materiais obtidos durante o trabalho, optou-se por subdividir o percurso da rota conforme a unidade político administrativo a que pertence. Entretanto, a Bolívia, por ter inserido em seu território o maior trajeto e por apresentar maior diversidade em termos de potencial paisagístico teve maior detalhamento na explanação a seguir. Essa, obedecendo a seqüência do desenvolvimento da viagem, começa a sua ordem apresentando o que tem no Brasil, na Bolívia, no Peru e, por fim, no Chile.

\section{Setor Brasileiro}

O Brasil, mais precisamente o estado do Mato Grosso, tem as suas potencialidades, para implantação da presente proposta, totalmente firmada sobre os diversos elementos presentes na paisagem do Pantanal mato-grossense. Este, em termos de fatos cênicos oferece inúmeras opções, principalmente vinculadas ao contexto da biodiversidade.

Geografia Ensino \& Pesquisa, v. 15, n. 3, p. $27-54$, set./dez. 2011

Garcia Netto, L. R; Avelino, P. H. M

ISSN 2236- 4994 

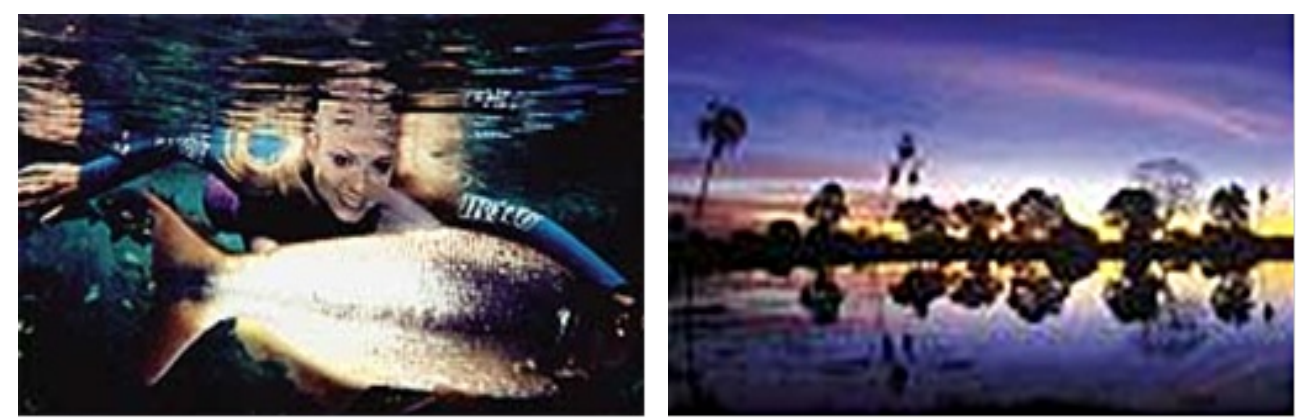

Figura 03— Mostra imagens peculiares do pantanal nas regiões de Bonito/MS e de Cáceres/MT. (SEDTUR/MT,2007)

Associado a esse conjunto, dependendo dos objetivos de interesse do visitante, ele também poderá usufruir dos aspectos relacionados as águas no período das cheias, além dos fatos próprios da origem de uma planície de inundação, como por exemplo, as feições de deposição sedimentar mostrando a sucessão dos depósitos sedimentares originados pela descarga dos rios durante as cheias, numa escala de grandeza que somente ocorre na Planície Pantaneira.

\section{Setor Boliviano}

Altitudes e interioridade são as duas características geográficas de expressividade neste país. De muitos contrastes é nesta parte da América do Sul que se encontram alguns dos locais mais elevados dos Andes - o Sajama (6.570 m.), o Ancohuma (6.550 m.) e o lllimani (6.458 m.). É na Bolívia que está localizada uma das regiões habitadas mais altas do mundo, o Altiplano com altitude média de $3.500 \mathrm{~m}$. Também é referência o lago Titicaca, lago navegável mais elevado do globo. Contrário a isso o território boliviano apresenta superfícies compostas pelas terras baixas do Chaco e da Amazônia.
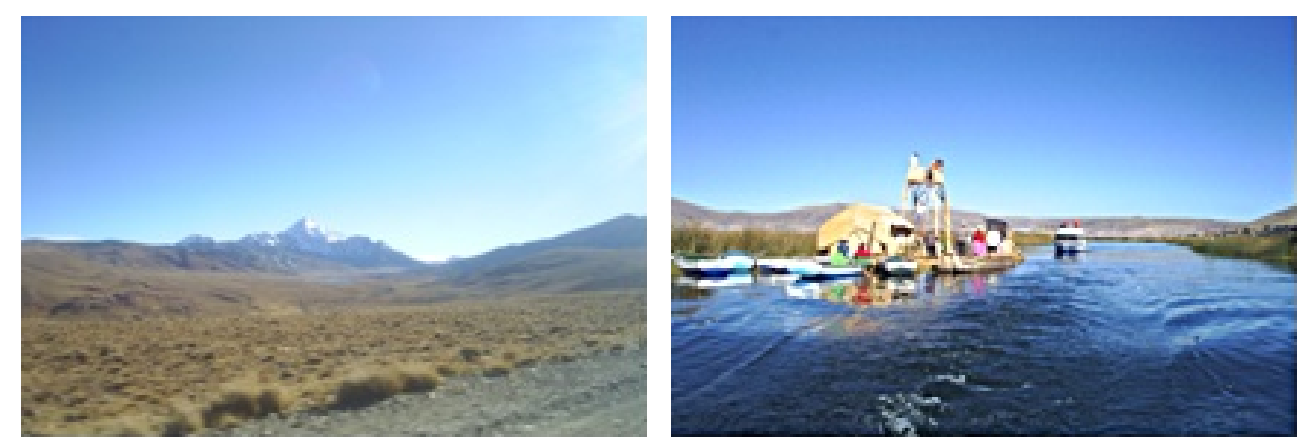

Figura 04- aspectos da região dos Andes boliviano e do Lago Titicaca.(Garcia Netto, 2007)

\section{Planícies e Planaltos rebaixados}

O setor leste boliviano é formado por terrenos baixos, correspondendo as superfícies das planícies aluviais e dos grandes pântanos, sobrepostos ao antigo escudo cristalino brasileiro, que aflora em longos trechos. No extremo sul tem-se o chaco boliviano, pantanoso durante a estação 

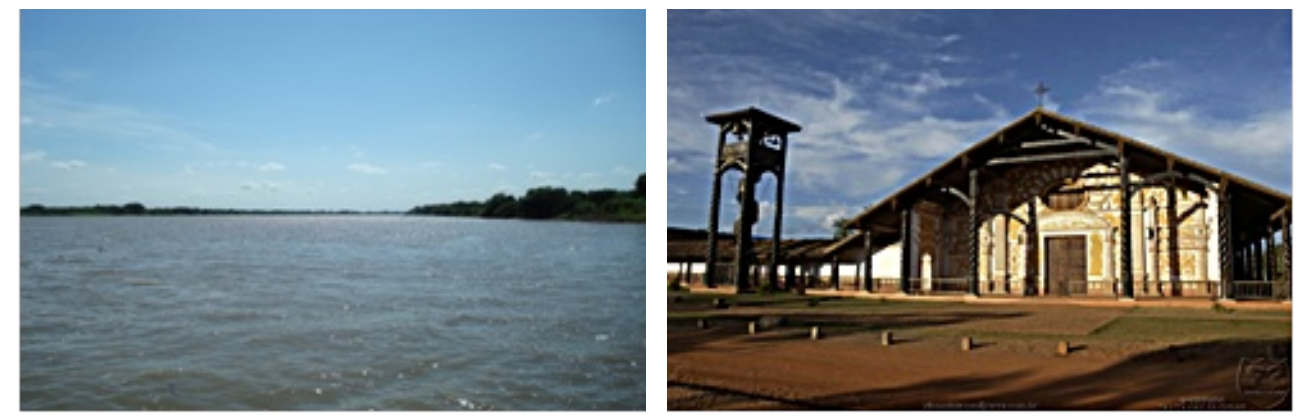

Figura 05 - Vista dos alagados do chaco boliviano, na estação chuvosa. E da arquitetura das Igrejas Jesuíticas existentes nas localidades de San Javier e San Ignacio de Velasco.(Vilson Jesus, 2007)

\section{Pré- Cordilheira}

A Pré-Cordilhiera corresponde a uma área montanhosa prévia à Cordilheira dos Andes, onde a faixa de altitudes varia em torno de 1700 a 3700 metros. É uma superfície onde se destaca os inúmeros aspectos morfológicos, perfazendo o conjunto de elementos necessários ao desenvolvimento do turismo em varias modalidades. Um exemplo é a área a NE da bacia do lago Titicaca, onde visualizamos uma sucessão de cadeias de montanhas extremamente altas, algumas excedendo $6.300 \mathrm{~m}$, caindo abruptamente sobre as planícies. Todo esse conjunto de formas tem a oferecer em seu percurso uma dose maior de adrenalina. Os visitantes passam por estradas contornando abismos, picos nevados, montanhas, planícies, vales e formações rochosas das mais variadas formas e cores. Tudo isso é complementado com a presença das Llamas, Cactos, Ciprestes, Flamingos e a presença do ser humano em suas construções de pedra e/ou barro, conforme pode ser visto a seguir na figura 05 .
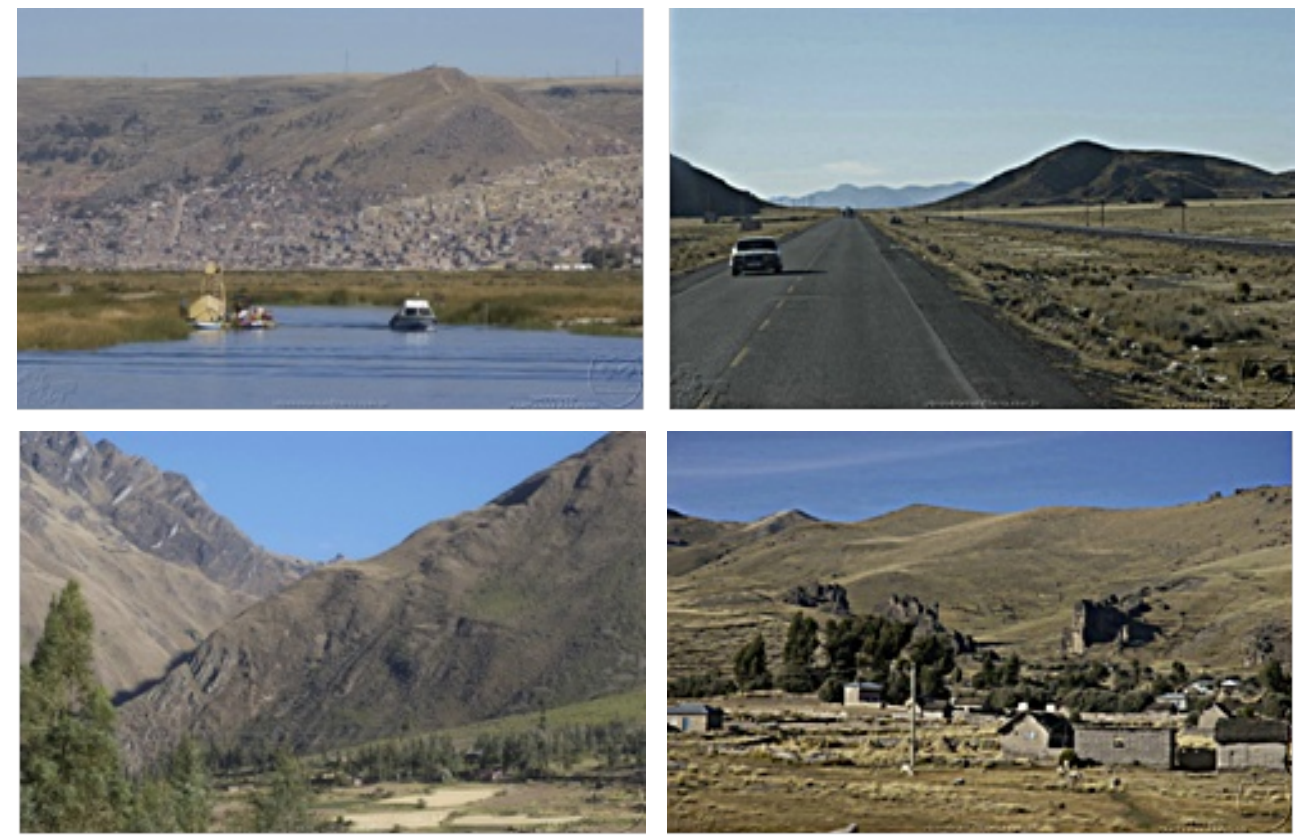

Figura 06 - Vista do Lago Titicaca, com a cidade de Puno (PE) ao fundo; As planícies formam a paisagem dominante junto à pré-cordilheira; Ao longo da Rota pode se observar uma sucessão de áreas desérticas e áreas de produção agrícola de subsistência, onde há possibilidade de acesso à água.(Vilson Jesus, 2007)

Geografia Ensino \& Pesquisa, v. 15, n.3, p. 27-54, set./dez. 2011

Garcia Netto, L. R; Avelino, P. H. M 
Cabe destacar que é neste setor do continente sul americano que a flora arbórea desaparece. Há ausência de árvores e fontes de água. A paisagem é formada por cadeias de montanhas desprovidas da cobertura vegetal. $O$ cenário é de montanhas sobre montanhas e desfiladeiros cortados por marcas de rios onde não há água. O Ichu, uma espécie de arbusto de altitude, domina a paisagem compartilhando a terra apenas com a Quenhua, uma pequena árvore de altitude, e claro, centenas de llamas, alpacas e vicunhas, figura 06. Enfim, na PréCordilheira se destaca a ocorrência de grandes paredões de cores que vão do marrom escuro ao quase rosado, conforme o tipo rochoso, que lhe dá sustentação.
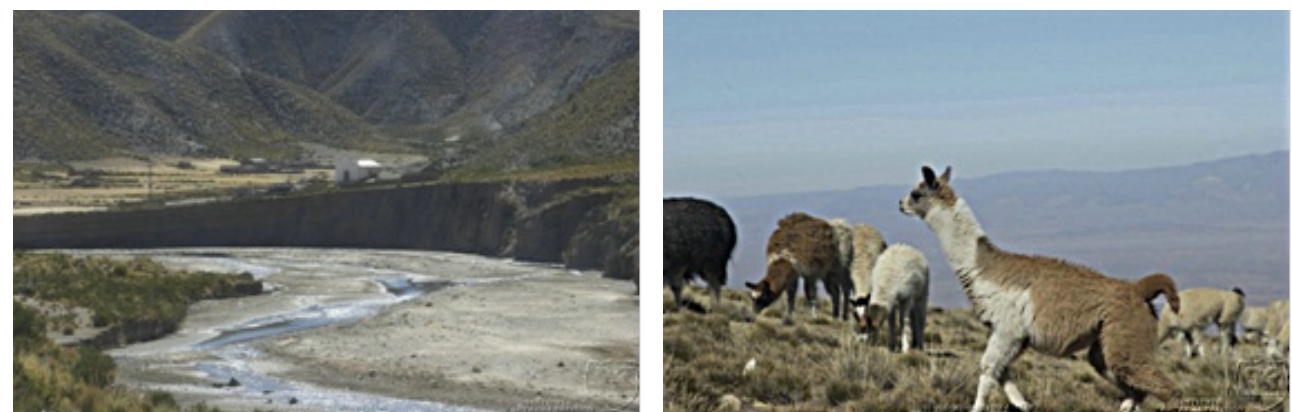

Figura 07- A paisagem se caracteriza pela escassez de água, é formada por cadeias de montanhas, desprovidas da cobertura vegetal. Fauna adaptada à áspera ambiental. (Vilson Jesus, 2007)

\section{Cordilheira}

A Cordilheira dos Andes é uma vasta cadeia montanhosa formada por um sistema contínuo de montanhas o longo da costa ocidental da América do Sul, constituída por estruturas geológicas terciárias. Possui aproximadamente $8.000 \mathrm{Km}$ de extensão e, em seus trechos mais largos, $160 \mathrm{Km}$ do extremo leste ao oeste. Apresenta uma altitude média em torno de $4000 \mathrm{~m} \mathrm{e}$ seu ponto culminante é o pico do Aconcágua ("A sentinela de pedra" em aymará) com 6962 metros, localizado próximo a cidade Mendoza na Argentina.

A Cordilheira dos Andes apresenta a sua topografia e distribuição geográfica diversificada, ou seja, na sua parte central, os Andes se alargam dando lugar a um planalto elevado denominado Altiplano com numerosos vales fluviais distribuídos longitudinalmente. É uma área relativamente grande adentrando pelos territórios da Bolívia, Peru e Chile. Nesta seqüência a cordilheira torna a estreitar-se no norte do Peru e se alarga novamente na Colômbia para estreitar-se e dividir-se ao entrar na Venezuela.

Precisamente, os Andes Centrais se estendem desde o Nudo de Pasco até o Macizo de las Tres Cruces. A disposição dos alinhamentos montanhosos é de dois eixos separados pelo Altiplano referido no parágrafo anterior. A altura máxima nesta região é o Nevado Sajama (6.542 m) localizado em território Boliviano e o Pissis $(6.882 \mathrm{~m})$ no setor do deserto de Atacama na Argentina. Ambos correspondem a cones de vulcões extintos.

$\mathrm{Na}$ Bolívia, os Andes se dividem em duas grandes cadeias de montanhas: a Oriental e a Ocidental. A cordilheira Ocidental é formada por vulcões inativos ou extintos, e suas rochas são formadas de lava vulcânica petrificada. Possui uma altitude de 3.700 metros, com 800 quilômetros de comprimento e 130 de largura. A cordilheira Oriental é composta de diversos

Geografia Ensino \& Pesquisa, v. 15, n.3, p. 27-54, set./dez. 2011

Rota Pantanal Pacífico - a maior aventura das Américas tipos de rochas e areia. É nesta parte da cordilheira que se encontra o glaciar Quelccaya (localizado no setor montanhoso oriental da Cordilheira peruana), um dos dois únicos glaciares planos na zona tropical do planeta. Esta singularidade possibilita estudos de seus gelos para avaliar as mudanças climáticas ocorridas no trópico desde a última Era Glacial. 

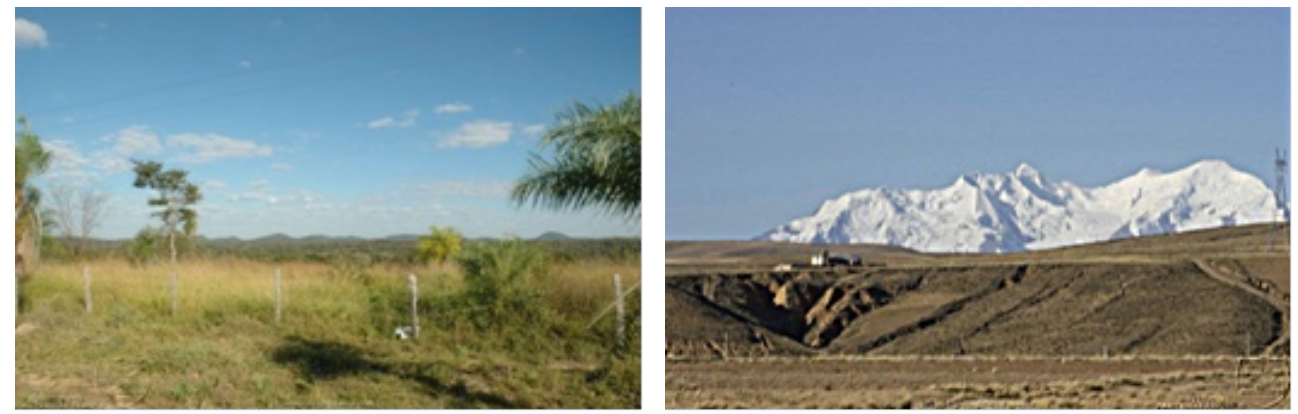

Figura 08- Região da savana boliviana ao sul e dos picos gelados, na região de La Paz .(Vilson Jesus, 2007)

No altiplano, em altitudes médias de 4.000 m estão o deserto de Uyuni e a cidade de La Paz, situada em um "canyon" na base de um arco cercada pelas várias saliências da cordilheira dos Andes. Esse cenário é destacado não só pelas inúmeras elevações, mas também pela presença da neve recobrindo os topos das montanhas e vulcões, constituindo um cenário bem arranjado e único no mundo. Nesta parte da Cordilheira as condições ambientais resultam do tipo climático seco e frio.
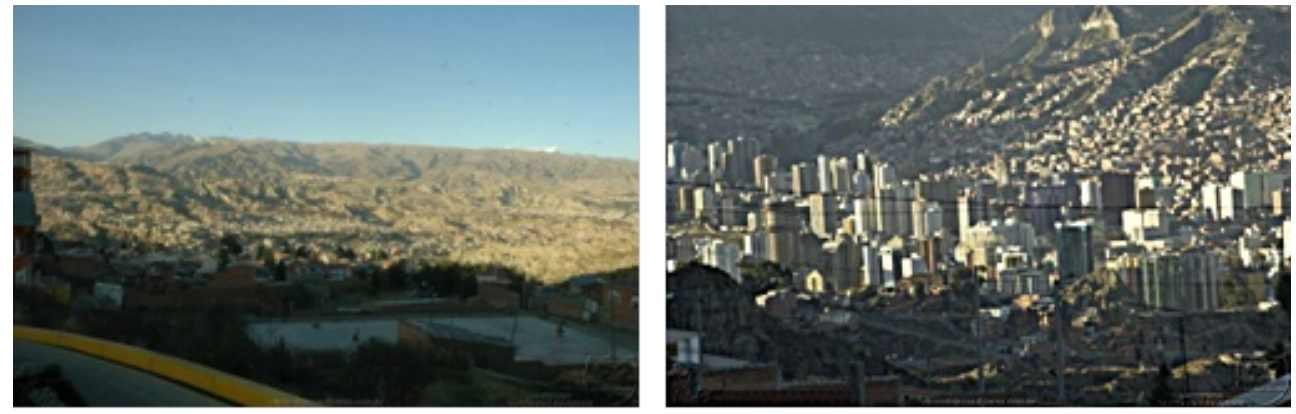

Figura 09_ A cidade de La Paz é algo "suigeneris", pois se localiza dentro de uma canyon.(Vilson Jesus, 2007)

Quanto ao Salar Uyuni, acredita-se que a formação do mesmo tenha ocorrido a cerca de 80 milhões de anos, quando nesta parte do continente existia um braço do Pacífico. Durante 0 processo de soerguimento da Cordilheira dos Andes, a água do oceano teria sido "aprisionada", formando, inicialmente, um grande lago salgado. Com o decorrer do tempo e a própria evolução dos processos geológicos o lago foi submetido a condições de temperaturas mais elevadas e pouca pluviosidade, ocasionando a evaporação da água e acumulação dos seus sais.

Localizado no sudoeste da Bolívia, o Salar de Uyuni faz fronteira com o Atacama (deserto de pedras e areia) no norte do Chile. São desertos próximos com características diferentes, compondo um dos lugares mais originais do mundo. Atração que sustenta "o projeto turístico boliviano: Bem vindo ao maior deserto de sal do planeta".
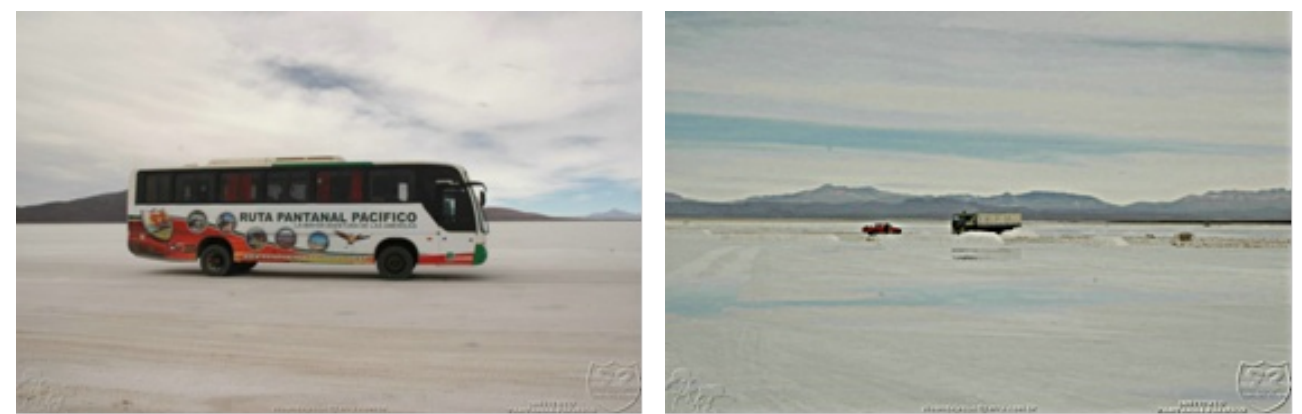

Figura 10- A presença dos salares tem se configurado em grande atrativo. Vista do Salar de Coipasa, junto a divida da Bolívia com Chile e Peru. (Vilson Jesus, 2007)

Geografia Ensino \& Pesquisa, v. 15, n.3, p. 27-54, set./dez. 2011

Garcia Netto, L. R; Avelino, P. H. M 
A grande coluna vertebral da América está repleta de passagens estreitas e escarpadas que se estendem entre as abruptas montanhas, com uma adaptação humana muito especial. A cidade de Oruro, situada a $3707 \mathrm{~m}$, por exemplo, ocupa uma área do extremo sul do altiplano. A pista de ski em Chacaltaya (5.300 mtrs.) se destaca por ser a mais alta do mundo e é amplamente utilizada por montanhistas para treinamentos, cursos de escalada em gelo e para a aclimatação.

O lago Titicaca com $8300 \mathrm{Km} 2$ está a situado a uma altitude de cerca de 3800 metros. A paisagem em seu entorno, principalmente a nordeste, é composta por montanhas que estão na faixa de 3000 a 6500 metros do nível do mar. As particularidades em relação a essa cadeia de montanhas é a própria forma da qual elas se posicionam em relação às superfícies. As montanhas mais elevadas caem formando quase um ângulo reto até se agregarem às áreas pouco acidentadas do Altiplano.

\section{Setor Peruano}

As informações em relação ao Peru serão discriminadas conforme o trajeto percorrido durante a expedição, ou seja, as áreas entre as cidades de Puno, Cusco, Machu Picchu, Arequipa e Tacna.

Primeiramente, o território Peruano apresenta a sua posição geográfica na parte oeste da América do Sul, na costa Sul do Oceano Pacífico, entre o Chile e o Equador. É um dos países sul-americano que apresenta uma vasta faixa de fronteira, colocando-o diretamente em contato com a Colômbia, Bolívia e Brasil, como pode ser obsevado na figura 01 .

O país é formado por três regiões distintas com um relevo muito particular, isto é, as Planícies da Costa Oeste, a Cordilheira dos Andes no centro e terras Baixas Orientais cobertas pela selva Amazônica:

> A primeira se refere a "franja" costeira do oeste banhada pelo Oceano Pacífico. É junto a essa unidade que ocorre a estreita zona de planícies desérticas, onde estão situadas algumas cidades, como por exemplo, a capital Lima com um quarto da população do país;

$>$ A segunda unidade atravessa o país de norte a sul, perfazendo as superfícies dos altos planaltos e os cumes montanhosos, onde se encontra inúmeras opções atrativas, dentre as quais a cidade perdida dos Incas - Machu Picchu;

> A terceira unidade, "Ceja de Selva", corresponde os flancos orientais da Amazônia montanhosa que varia entre 2300 e 4000 metros de altitude. É uma região que apresenta um relevo abrupto. Junto a essa, nos setores mais rebaixados do terreno - entre 400 e 1000 metros de altitude - tem-se a unidade morfológica regionalmente denominada de "Rupa" ou Floresta Elevada. Em termos gerais essa superfície apresenta um relevo íngreme nos montes e um relevo plano no fundo dos vales, tornando-se locais propícios ao uso agrícola.

Geografia Ensino \& Pesquisa, v. 15, n.3, p. 27-54, set./dez. 2011

Rota Pantanal Pacífico - a maior aventura das Américas
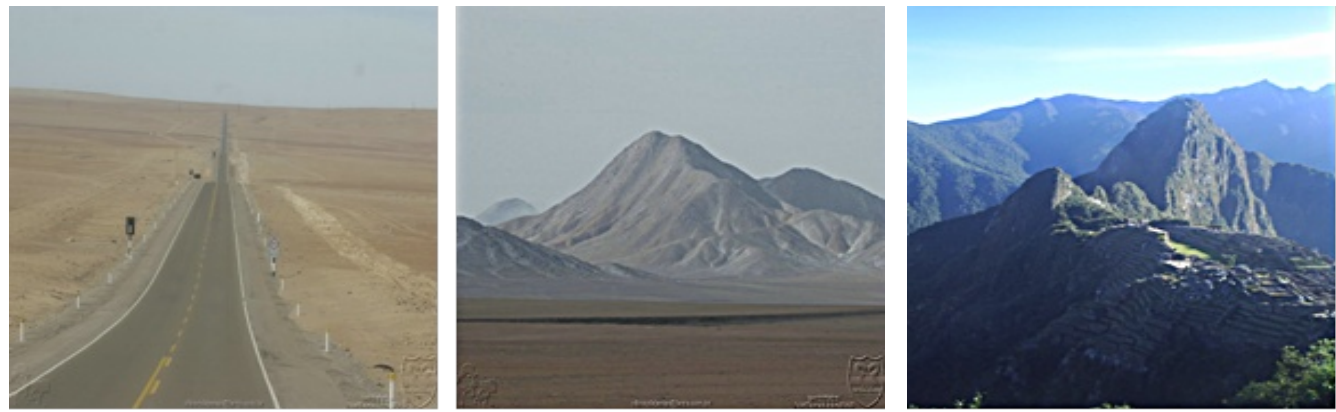

Figura 11- O país é formado por três regiões distintas com um relevo muito particular, isto é, as Planícies da Costa Oeste, as superfícies dos altos planaltos e os cumes montanhosos, onde se encontra inúmeras opções atrativas, dentre as quais a cidade perdida dos Incas - Machu Picchu. (Vilson Jesus, 2007) 
Localizado no Departamento de Cusco, o caminho Inca a Machu Picchu é a rota mais concorrida do Perú e com certeza uma das mais espetaculares da América, formando parte dos mais de $23.000 \mathrm{~km}$ de caminhos construídos pelos Incas na América do Sul. O complexo histórico-arquitetônico de Machu Picchu está instalado sobre uma montanha cercada pelo vale encaixado (cañon) do río Urubamba. Constituía o centro de culto e observação astronômica dos Incas (fig.11, cena três). 0 território era formado de duas grandes áreas: uma agrícola, formada principalmente por escadarias e recintos de armazenagem de alimentos; e outra urbana, na qual destaca a zona sagrada, com templos, praças e mausoléus reais trabalhados com um incrível nível de perfeição. As escadas e canais de pedra lavrada são uma constante ao longo deste singular sítio arqueológico.

Por fim, as planícies costeiras ocidentais, conhecidas como Costa, estão separadas pelas elevadas e escarpadas montanha da Cordilheira dos Andes. É nesta região, junto a fronteira com a Bolívia que ocorre o lago Titicaca que tem como particularidade ser o lago navegável de maior altitude do mundo.
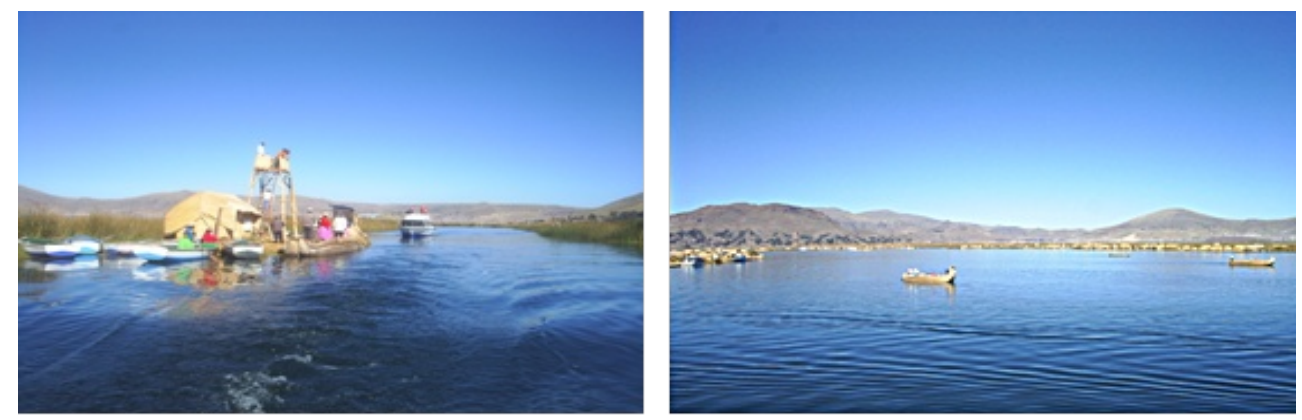

Figura 12- Cenas do Lago Titicaca, com as planícies a os altiplanos às suas margens. Na primeira cena, a entrada da Reserva dos Uros, povos que habitam as ilhas flutuantes. (Vilson Jesus, 2007)

A parte serrana da Cordilheira dos Andes corresponde cerca de 30\% do Peru e várias das montanhas mais elevadas do planeta estão situadas neste setor da mesma, como por exemplo, Huascaran (6768m) e Yerupaja (6634 m). Outro detalhe que cabe aqui destacar é que grande parte do sudeste da região elevada do Peru fica em torno do Lago Titicaca que se localiza nas vastas planícies localmente denominadas punas ou altiplanos. Na parte sul do país tem mais um atrativo, o Canyon Colca que mesmo não sendo tão divulgado chega a categoria do Canyon mais profundo do mundo.

\section{Setor Chileno}

Em relação ao Chile, as informações contidas aqui corresponderão ao trajeto entre as cidades de Tacna (Peru) e lquique (Chile). Sendo assim, o presente relato será de alguns conteúdos relacionados com ao Deserto de Atacama.

Primeiramente, o Chile corresponde a uma longa faixa que se estende do meio da costa oeste da América do Sul até o extremo meridional do continente. Essa particularidade permite ao Chile apresentar condições do meio físico extremamente distintas, devido a abrangência de diversas latitudes em seu território, conferindo-lhes, por exemplo, diferentes tipos de clima, vegetação e, conseqüentemente, influenciado na própria distribuição populacional no país.

O clima do Chile varia muito, passando pelo mais árido deserto do planeta no setor norte ao tipo mediterrâneo nos vales da parte central até chegar a região fria e úmida do sul. As características mediterrânicas do vale central torna essa parte do país ideal para 0 cultivo de frutos de mesa e produção de videiras (matéria prima para a produção de vinhos). Ambos

Geografia Ensino \& Pesquisa, v. 15, n.3, p. 27-54, set./dez. 2011

Garcia Netto, L. R; Avelino, P. H. M 
constituem os produtos de exportação importantes. Em termos gerais isso é expressado da seguinte forma, ao norte tem-se o mais árido deserto do planeta (Atacama), no centro clima agradável em todos os aspectos e ao sul encontram-se as geladas florestas úmidas presentes na região da Patagônia Chilena.

Outro fato interessante em relação a posição geográfica do país é a sua localização sobre a placa tectônica de Nazca, a qual encontra-se em plena atividade geológica no que se refere aos processos globais de evolução dos continentes. Isso possibilita a ocorrência de uma série de eventos naturais, como por exemplo, vulcanismos, gêisers, montanhas de estruturas dobradas e outras. Esse acontecimento confere ao território chileno particularidades relacionadas às formas do relevo que, em termos gerais se distribuem da seguinte forma: a leste, o país é serpenteado pela Cordilheira dos Andes; a oeste, em seqüência à área montanhosa da Cordilheira dos Andes, se destaca a presença de uma costa com grande declive. Tudo isso vai se refletir nas condições de profundidade do Oceano Pacífico, ou seja, mesmo próximo ao litoral este apresenta grandes profundidades, reflexo da grande atividade sísmica ao longo da costa devido aos constantes choques da Placa de Nazca com a Placa Sul-americana. Enfim, o país apresenta uma grande variedade de paisagens, como por exemplo, os cumes andinos, os vulcões coroados de neve, vales amplos, desertos, fiordes (corredores estreitos e profundos presentes em litoral alto, cavados pela erosão glaciária), glaciares, lagos e praias.
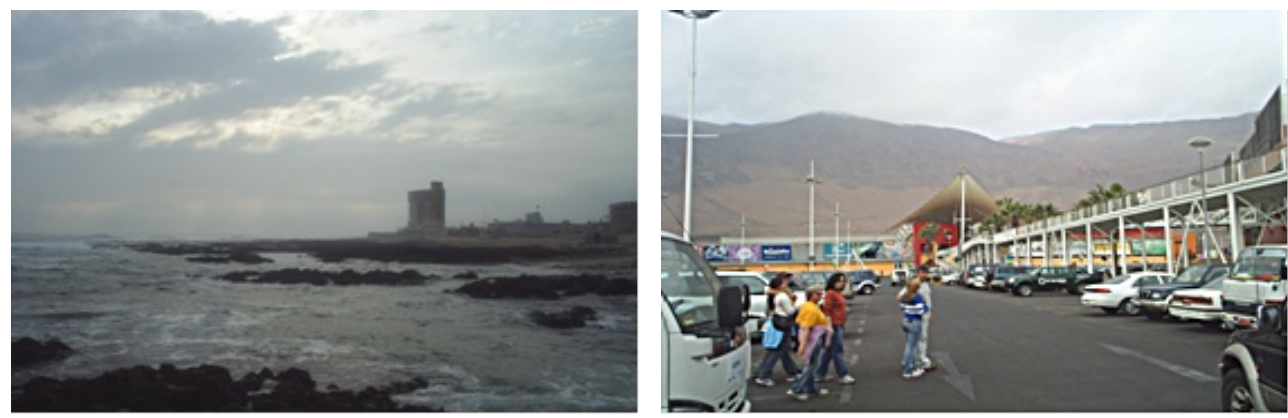

Figura 13- Iquique convive com dois ambientes distintos, de costa (cena um) e de montanha (cena dois). Nesta região, há 50 anos não chove. (Vilson Jesus, 2007)

Em relação ao deserto de Atacama, cabe destacar que o mesmo constitui a região mais seca do planeta. Há lugares no sul do deserto, entre a fronteira do Chile com o Peru que não chove a mais de 50 anos. Entretanto, apesar de não haver chuvas é quase comum nevar em partes da região, junto aos topos dos vulcões. O Deserto do Atacama fica localizado no norte do Chile, entre a costa do Pacífico e a Cordilheira dos Andes, abrigando uma área de aproximadamente $200000 \mathrm{Km} 2$.

Em termos de condições ambientais, essa área apresenta elementos do conjunto que constitui os locais de baixa e/ou ausência de precipitações, além da destacada oscilação térmica. É neste contexto que as estepes de grande altitude, em conjunto com a fauna, fazem da área mais uma opção de visitação no país, além da presença dos Oásis que oferecem um conjunto paisagístico completamente alheio ao contexto geral.

Geografia Ensino \& Pesquisa, v. 15, n.3, p. 27-54, set./dez. 2011

Rota Pantanal Pacífico - a maior aventura das Américas

Outro fato que constitui uma das maiores atrações do Atacama são os salares, onde a paisagem de "deserto de sal" apresenta-se povoada por flamingos e formas especiais como as termas naturais, gêiseres e as lagoas coloridas. As principais cidades turísticas do norte chileno são Arica, Iquique, Calama, San Pedro de Atacama e Antofagasta. Dessas, exceto Calama e 
San Pedro de Atacama, todas são cidades costeiras, que oferecem praias. A partir das cidades litorâneas, 0 acesso ao altiplano e serras é possível, uma vez que o sistema viário do país não oferece grandes obstáculos, fazendo com que cada cidade ofereça meios de chegar à referida região. Próximo ao limite setentrional da região, junto as cidades de Copiapó e La Serena tem-se acesso aos vales transversais que se estendem de leste a oeste. Estes são conhecidos por apresentar o céu mais límpido do hemisfério sul, fato explorado por astrônomos profissionais e simpatizantes do mundo inteiro.

Antes de finalizar, também é importante chamar a atenção para as possibilidades em relação a Arqueologia. Dentre os locais com essa finalidade têm-se as localidades de "Pukara de Quitor" (ruínas de uma fortaleza pré-inca), o sítio arqueológico das Ruínas de "Tulor" (antigo povoado do deserto de três mil anos atrás o qual se encontrava sepultado na areia) e o sítio arqueológico de "Catarpe" (antigo centro administrativo do Império Inca).

Enfim, o deserto de Atacama é uma opção para várias modalidades turísticas, como por exemplo, a prática do Montanhismo, Montaria, Off-road e Mountain bike e atividades relacionadas à Arqueologia, pois apresenta lugares com artefatos arqueológicos e históricos.

\section{Resultados Alcançados}

Como resultado acadêmico de maior relevância até agora obtido, está a dissertação de mestrado, intitulada "Análise da viabilidade da implantação da Rota Pantanal Pacífico", orientada pelo Prof. Dr. Luiz da Rosa Garcia Netto, defendida pela Turismóloga Vanilde Alves de Carvalho. Idealizadora do Projeto.

Como segundo produto, está o reconhecimento pelo nosso esforço no sentido de divulgação do Projeto. Assim, consideramos muito importante, o convite para participarmos (GEEPI), em um espaço de discussão, sobre a Rota Pantanal Pacífico, no $8^{\circ}$. Congresso Nacional de Geografia \& $1^{0}$. Congresso Internacional de Geografia, em Arequipa, 29 de Noviembre al 01 de Diciembre 2007, promovido pela Sociedad Geográfica de Lima, la Pontificia Universidad Católica del Perú con su Centro de Investigación en Geografía Aplicada (CIGA), la Universidad Nacional Mayor de San Marcos y la Universidad Nacional de San Agustín de Arequipa.

Neste evento foram apresentados e debatidos em mesa de discussão quatro trabalhos [(1) Rota Pantanal Pacífico: o papel da Bolívia na integração sul-americana, (2) Rota Pantanal Pacífico: um projeto acadêmico, uma estratégia de negócios, (3) Aplicação das geotecnologias como ferramenta de auxilio no mapeamento turístico: um exemplo aplicado a Rota Pantanal Pacifico (Brasil, Bolívia, Peru e Chile) e, (4) Turismo, a cultura integrando os povos sulamericanos: Rota Pantanal Pacífico]. Foram apresentados ainda, algo entorno de outros doze trabalhos de alunos do PPGGeo \& Graduação/UFMT, que enviaram trabalhos mas não puderam participar desse Encontro Internacional, todos foram incentivados pelos contatos iniciados pelo nosso projeto.

Nosso grupo foi convidado para participar de outros eventos relacionados com a Rota:

$>$ Em nível regional, XV Encontro Sul-mato-grossense de Geógrafos, de 05 a 09/11/2007 no Campus da UFMS em Corumbá (MS);

Geografia Ensino \& Pesquisa, v. 15, n.3, p. 27-54, set./dez. 2011

Garcia Netto, L. R; Avelino, P. H. M

ISSN 2236- 4994 
$>$ Em nível internacional, $1^{\circ}$ Encuentro Internacional de los Municípios de Frontera Brasil - Bolívia, realizado de 28 a 30/10/2007 em Comodoro (MT)

$>4^{\circ}$. Seminário Internacional de Turismo de Fronteira - FRONTUR 2007, realizado em Cuiabá (MT) de 21 a 23/11/2007.
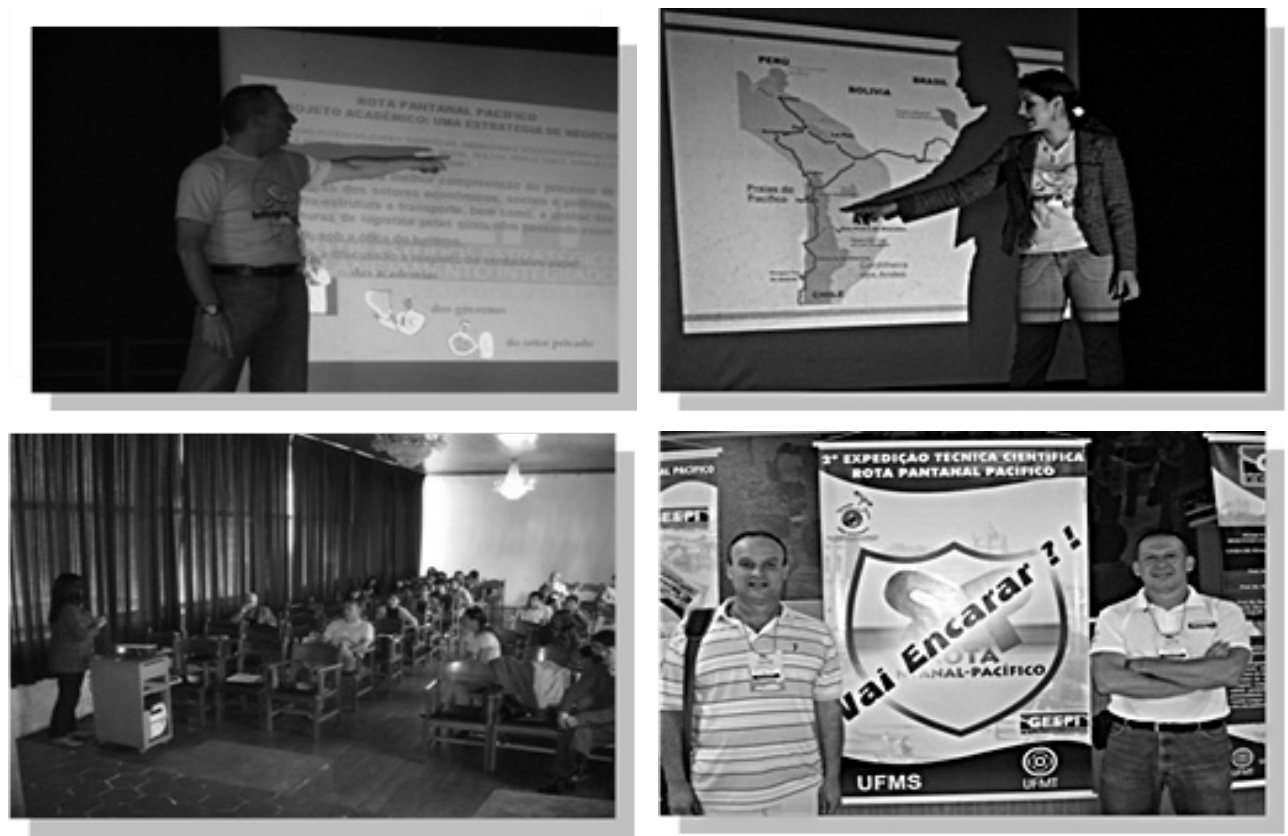

Figura 12- Participações em eventos: $8^{\circ}$. Congresso Nacional de Geografia \& $1^{\circ}$. Congresso Internacional de Geografia, em Arequipa, 29 de Noviembre al 01 de Diciembre 2007, promovido pela Sociedad Geográfica de Lima, la Pontificia Universidad Católica del Perú \& no $1^{\circ}$ Encuentro Internacional de los Municípios de Frontera Brasil - Bolívia, realizado de 28 a 30/10/2007 em Comodoro (MT) e do $4^{\circ}$. Seminário Internacional de Turismo de Fronteira - FRONTUR 2007, em Cuiabá. (Vilson Jesus, 2007)

\section{Com relação aos aspectos físicos}

Na perspectiva da Geografia o lugar tem a conotação de nos apresentar as diferenças sobre o espaço geográfico que na visão humanizada nada mais é do que o produto das interações do homem com a natureza. Nesta questão é de "praxe" trazermos a tona a questão da paisagem, pois é ela que nos coloca, em primeira instância, a par do que seria o espaço geográfico. Neste contexto, os conceitos de paisagem e espaço geográfico são de extrema importância para as questões relacionadas com as atividades do homem, em especial com as propostas vinculadas ao turismo planejado. Sendo assim, os conceitos de paisagem propostos por autores como, Tricart (1977), Santos (1988), Sauer (1998), Grigoryev (1968), Bertrand, (1971) Ross (2006) apresentam o conteúdo teórico necessário para a sustentação do entendimento que dinamiza cada lugar com as suas particularidades, fato um tanto interessante quando se trata de projetos para a referida atividade.

\section{Outros produtos}

Geografia Ensino \& Pesquisa, v. 15, n.3, p. 27-54, set./dez. 2011

Rota Pantanal Pacífico - a maior aventura das Américas

Ainda com relação aos resultados da viagem de estudos acima mencionada, foram realizados levantamentos de dados geográficos, turísticos e institucionais em órgãos públicos e privados; apresentação do Projeto Rota Pantanal Pacífico em eventos específicos como palestras e conferências em universidades e instituições públicas; coletivas de imprensa para 
rádio, jornais e redes de televisão; entrega de material promocional do projeto; articulação para participação em futuros eventos; e sondagem para futuras parcerias acadêmicas e técnicas.

Um dos produtos que já se encontra praticamente concluído é um Banco de Imagens, com mais de 12.000 fotos.

Empresarialmente, as perspectivas têm sido muito promissoras, potencializadas pelo envolvimento dos SEBRAE's de Mato Grosso e Mato Grosso do Sul. E das CAINCO's (Câmaras de Indústria e Comércio) dos países visitados.

\section{Considerações Finais}

Realizar este trabalho está sendo um grande desafio. É gratificante pesquisar e fazer parte da pesquisa. Abaixo, mostramos o primeiro esboço da rota. Quando nos sentamos para uma primeira discussão sobre a viabilidade do projeto! Apesar de o tema manter-se sem nenhuma alteração quanto aos objetivos propostos, pode-se dizer que ganhou vida própria durante a pesquisa. Tudo partiu desta $1^{\text {a }}$ figura que hoje corresponde ao cerne da pesquisa. E resultou na proposta da Rota Pantanal-Pacífico que corresponde a um dos maiores projetos de integração humana das Américas e considerada uma das maiores rotas turísticas e culturais do mundo. Tão logo saíram as primeiras publicações, a pesquisa chamou muito a atenção, despertando interesses pelo assunto.

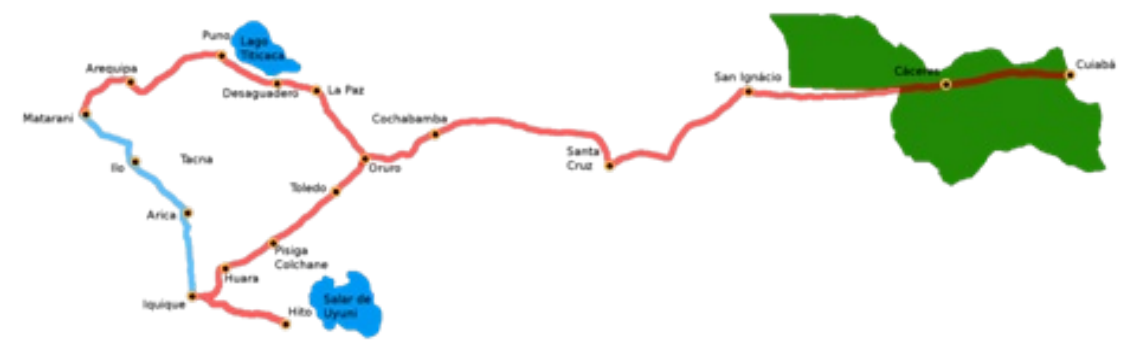

Figura 13 - Primeiro esboço concebido da rota. As primeiras dicussões partiram desse desenho.

Fonte: IPP 2006.

\section{Algumas discussões interessantes que ainda necessitam de mais estudos}

\section{Com relação ao produto Rota Pantanal Pacífico [RPP}

A Rota está pronta para ser comercializada. O que falta é o "despertar do mercado" regional e da indústria turística dos países pela qual passa. Basta adotarem a Rota como "uma grande oportunidade de negócio", ou um amplo mercado de relações comerciais, formatando novos produtos, melhorando e agregando valores aos existentes.

É interessante observar que pesquisas indicam o crescimento significativo da indústria turística em nível global. Dados recentes da OMT apontam um crescimento de $8,1 \%$ para 0 mercado asiático, o dobro do crescimento da economia mundial que é de 4,5\%, e 7,6\% para 0 mercado Ásia - Pacífico e 4\%, para os mercados Europa e Américas. O turismo apresentou em 2007, $04^{\circ}$ ano consecutivo de crescimento acima da economia mundial, com um movimento entre 880 a 900 milhões de viagens (OMT, 2007). Dados como estes justificam propostas como a

Geografia Ensino \& Pesquisa, v. 15, n.3, p. 27-54, set./dez. 2011

Garcia Netto, L. R; Avelino, P. H. M 
da Rota, bem como indicam as tendências do mercado mundial que sinalizam crescimentos significativos e indicadores otimistas para o surgimento de novos produtos dentro dos gargalos existentes.

E, neste caso, a Bolívia como país central da Rota representa dois grandes extremos: país mais rico em atrativos, responsável pela viabilidade geográfica e de deslocamento, e também grande empecilho sócio-político, pois a situação inconstante do país entre conflitos sociais e políticos internos e externos, gera especulações positivas e negativas. Assim, o apoio do governo boliviano em assumir esse projeto para si, como um de seus instrumentos de desenvolvimento regional integrado, é uma expectativa!

$\underline{0} \underline{\text { interesse das }} \underline{\text { Instituições }} \underline{\text { de ensino, no que tange às pesquisa acadêmicas }}$

A Rota surgiu no contexto acadêmico, sendo formulada como projeto de estudo, foi financiado como projeto acadêmico. Nesse sentido, se espera mais interesse, mais inserção das universidades, tanto públicas quanto privadas, e a realização de novos estudos, intercâmbio entre os países. Espera-se, no futuro bem próximo, que a RPP possa ajudar a compor uma rede de pesquisa universitária integrada para a produção e disponibilização do conhecimento a sociedade que tanto carece de informação.

A aceitação do tema nas IES proporcionou a realização de uma expedição técnica-cientííca liderada pelo Grupo de Estudos Estratégicos e Pesquisas Integradas - GEEPI, através do Programa de Pós-graduação em Geografia da UFMT com o apoio do Programa de Amparo à Pesquisa do Estado de Mato Grosso - FAPEMAT. Em parceria com o grupo de estudos DIGEAGEOIUFMS.

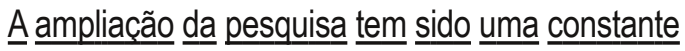

O Peru foi onde a proposta avançou e ganhou mais notoriedade, principalmente devido ao interesse da iniciativa privada. Isso facilitou a participação em congressos acadêmicos e eventos técnicos dos governos e eventos turísticos motivados e gerados pela aceitação da proposta da Rota.

$O$ fato da Argentina se interessar e ingressar com mais uma alternativa de enriquecimento dos atrativos da Rota nos leva a considerar o sucesso da proposta. A solicitação surgiu por parte da Embaixada da Argentina que, tão logo tomou conhecimento, tratou de solicitar a inclusão de seu país no projeto. Na realidade sua inclusão se dá pelo noroeste do País e com grande parte da Puna de Atacama, inserindo desta forma mais uma grande área geográfica com importantes atrativos turísticos.

No Brasil, país de origem da Rota, tem-se por resultado vários momentos de inserção da proposta em eventos oficiais, tanto do governo estadual, quanto federal, especialmente com 0 Ministério do Turismo e Ministério de Relações Exteriores. Pode-se considerar ainda, a adesão de todo o centro-oeste brasileiro e noroeste do Paraguai, mas isso dependerá do retorno que cada região-país poderá dispor/oferecer para a consolidação da Rota, como produto turístico. Essa expansão da Rota implicará num rearranjo de todos os encaminhamentos dados até agora, inclusive do mapa, figura 14.

Alguns órgãos internacionais, como a OTCA - Organização do Tratado de Cooperação Amazônica, a CAF - Corporação Andina de Fomento, bem como a IIRSA do Brasil, também se interessaram em conhecer a proposta da Rota e se colocaram à disposição para futuras parcerias, o que deverá ser articulado a partir de 2008. 
Parte do sucesso se deve à decisão de um grande grupo de empresários do setor industrial, comercial e turístico, em participar de rodadas de negócios, mesas redondas e "workshops" eventos que estão previstos para acontecerem no decorrer de 2008, dentro do eixo da Rota.

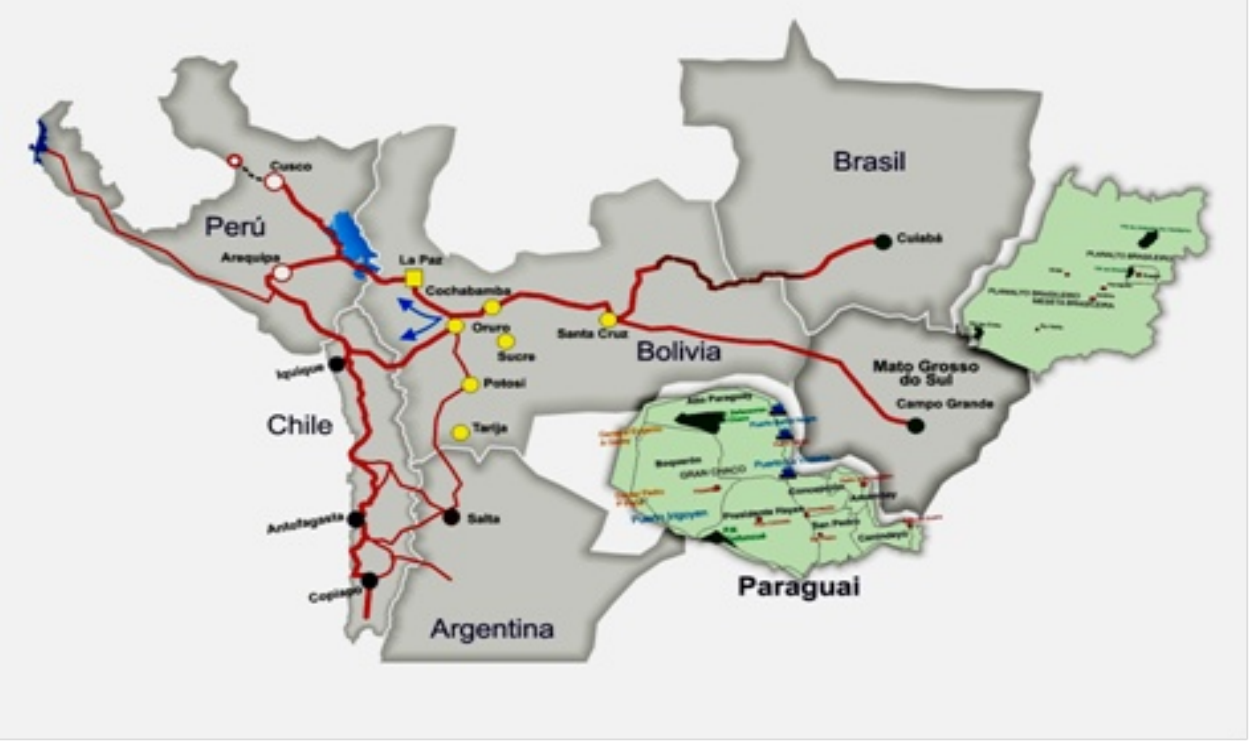

Figura 14 - Esboço do mapa com a inclusão de todo Centro Oeste do Brasil e Noroeste do Paraguai. Fonte: IPP 2008.

Bem, entre as melhores justificativas que poderíamos apresentar de consolidação da Rota Pantanal-Pacífico, além de tudo o que foi apresentado, estão as opções dos destinos turísticos, considerados únicos no mundo, que a torna a MAIOR AVENTURA DAS AMÉRICAS. E, que a potencializa como produto forte e definitivo no mercado mundial de turismo, como uma das mais belas Rotas do mundo.

\section{Pantanal - a maior planície alagável do Mundo \\ Missões dos Chiquitos - o único circuito missional intacto nas Américas \\ Lago Titicaca - o lago navegável mais alto do mundo \\ Cânions de Colca e Cotahuasi - os vales mais profundos do mundo \\ Salar de Uyuni - a maior salina e maravilha natural do mundo}

Forte Samaipata - considerado o maior monumento de arte rupestre do continente

Deserto do Atacama - o deserto mais árido do mundo

Cordilheria dos Andes - a maior cadeia de montanhas das Américas

Machu Picchu - Maravilha Cultural do mundo

Cusco - uma das regiões mais visitadas no mundo

Trem das Nuvens - 0 trem mais alto do mundo

Cidade de Sucre - capital mundial da arquitetura barroca

Uyuni, Vulcão Sud Lipez, Salar de Chiguna, Laguna Colorada e Laguna Verde considerados das paisagens mais impressionantes do mundo

A Rota é viável? A resposta é sim! A Rota Pantanal-Pacífico é viável.

Geografia Ensino \& Pesquisa, v. 15, n.3, p. 27-54, set./dez. 2011

Garcia Netto, L. R; Avelino, P. H. M 


\section{Referências Bibliográficas}

ACERENZA, Miguel Angel. Promoção Turística: Um Enfoque Metodológico - São Paulo: Pioneiro, 1991.

ANDRADE, José Vicente de. TURISMO Fundamentos e Dimensões. São Paulo: Ática, 1998.

ANDRADE, Manuel Correia de. Geografia Econômica, 12 ed, São Paulo: Atlas, 1998.

ANSARAH, Marília Gomes dos Reis. TURISMO Segmentação de Mercado. São Paulo: Futura, 1999.

BARAT, Josef. A Evolução dos Transportes no Brasil. - Rio de janeiro: FIBGE/IPEA, 1978.

BECKER, Berta K.; MIRANDA, Mariana.; MACHADO, Lia O. Fronteira Amazônica Questão sobre a gestão do Território. UNB/UFRJ, 1990, Brasília/ Rio de Janeiro.

BENI, Mário Carlos. Análise estrutural do turismo. 3. ed. São Paulo: SENAC, 2000.

BISSOLI, Maria Angela Marques Ambrizi. Planejamento Turístico Municipal, com suporte em sistemas de informações. São Paulo: Futura, 1999.

BNDES: Eixos Nacionais de Integração e Desenvolvimento, 1998, (mimeo)

BOULLÓN, Roberto C. Planejamento do espaço turístico; tradução: Josely Vianna Baptista. Bauru: EDUCS, 2002.

BRUN, Argemiro L. Integração do Cone Sul. ljuí, UNIJUÍ, 1991.

CONFERENCIA DE MINISTROS DE TRANSPORTES, COMUNICACIONES Y OBRAS PÚBLICAS DE AMERICA DEL SUR. Proyectos de infraestructura de transportes prioritarios para la integración del America del Sur. [S. I. :s.n .], 1994. 1 V.

CORREDORES. Interegionales de transportes de America del Sur. Montevideo: Associón Latinaamericana de Integración, 1992. 1 V.

DANTAS, Marcos Ribeiro. Nova saída para o Pacífico-Santa Rosa do Puros- Termópilas: Ligação Rodoviária Rio Branco- Lima: [S. I. :s.n .], 1994. 1 V.

EGLER, C.A.G. Eixos Nacionais de Integração e Desenvolvimento: prováveis impactos ambientais, 1999 (mimeo).

EQUADOR. Secretaria Pró-Tempore. Comisión Especial de Transporte da Amazônia. Tratado de Cooperação Amazónica; características de La Infraestructura del transporte en la región Amazónica. Quito: Secretaria Pró-Tempore, 1991. 1 V.

FARIA, Dóris Santos de e Kátia Saraiva Carneiro. Brasília: Universidade de Brasília, 2001

GARCIA - NETTO, Luiz da Rosa \& MIRANDOLA-AVELINO, Patrícia Helena. Rota Pantanal Pacífico - um projeto acadêmico / uma estratégia de negócios. 80 CONGRESO NACIONAL Y 10 CONGRESO INTERNACIONAL DE GEOGRAFIA. Arequipa, Perú, 2007.

GARCIA - NETTO, Luiz da Rosa \& MIRANDOLA-AVELINO, Patrícia Helena ROTA PANTANAL PACÍFICO UM PROJETO ACADÊMICO DE PESQUISA APLICADA. XV Encontro Sul-mato-grossense de Geógrafos. Ed. UFMS. Corumbá, 2008.

IGNARRA, Luiz Renato. Fundamentos do Turismo. São Paulo : Pioneira, 1999.

Geografia Ensino \& Pesquisa, v. 15, n.3, p. 27-54, set./dez. 2011

Rota Pantanal Pacífico - a maior aventura das Américas
INSTITUTO PARA A INTEGRACIÓN DE AMERICA LATINA - INTAL. Integración Física MERCOSURBolivia - Chile; La contribuición potencial de los ferrocarriles. La Paz: lan Thomsom, 1995. 1V.

IPEA. Eixos Nacionais de Desenvolvimento e Integração - 1995/1998 Quatro Anos de Transformações, 1999.

LAGE, Beatriz Helena Gelas, MILONE, Paulo Cesar. Turismo: teoria e prática. - São Paulo : Atlas 2000.

LARAIA, Roque de Barros. Cultura um conceito antropológico. 11. ed. Rio de Janeiro: Jorge Zagar, 1997. 
LENCIONE, S. Região e Geografia. São Paulo: EDUSP, 2003.

MENEZES, Alfredo da Mota. Do Sonho à Realidade - A Integração Econômica Latino-Americana, São Paulo: Alfa-Omega, 1990.

MIRANDOLA-AVELINO, Patrícia Helena \& GARCIA - NETTO, Luiz da Rosa. Aplicação das Geotecnologias Como Ferramenta De Auxilio No Mapeamento Turístico: Um Exemplo Aplicado A Rota Pantanal Pacifico (Brasil, Bolívia, Peru E Chile). 80 CONGRESO NACIONAL Y 10 CONGRESO INTERNACIONAL DE GEOGRAFIA. Arequipa, Perú, 2007.

MOLINA, E. Sergio. Planejamento integral do Turismo: um enfoque para a América Latina; tradução: Carlos Valero. Bauru: EDUCS, 2001.

MUYLAERT, Roberto. Marketing cultural \& comunicação dirigida. 4. ed. São Paulo: Globo, 1995.

OLIVEIRA, Antonio Pereira. Turismo e Desenvolvimento. $2^{\circ}$ edição. São Paulo: Atlas, 2000.

PERU. Ministerio de Transportes y Cominiciaiones. Servicio Nacional de Caminos. Rede vial. Laz Paz: [s.n .], 1993. 1V.

PITNO, Gislaiene F.P.M. Mato Grosso e Bolívia: Corredor de Integração e Desenvolvimento. Dissertação de Mestrado, UFMT, 2006 (mimeo).

PORTUGUEZ, Anderson Pereira. Agroturismo e desenvolvimento regional. São Paulo: Hucitec, 1999.

RASMUSSEN, U.W. Manual da metodologia do planejamento estratégico: uma ferramenta científica da transição empresarial do presente para o futuro adotado para o âmbito operacional brasileiro. São Paulo: Aduaneiras, 1990.

RODRIGUES, Adyr Balastreri. Turismo e espaço: rumo a um conhecimento transdisciplinar. 2. ed. São Paulo: Hucitec, 1999.

RUSCHIMANN. Doris Van de Meene. Turismo: como aprender como ensinar. 2. ed. São Paulo: SENAC, 2000.

SANT'ANNA, J.A. - Possibilidades de Interligação Terrestres (Rodo-ferroviárias e Fluviais) entre o Brasil e 0 Pacífico. In: Boletim da Diplomacia Econômica, 10, Dez. 91:Jan92.

SEMINARIO - Eixos de integração Sul-Americana e Corredores de Exportação. Anais. Brasília: Ministério dos Transportes. 1995. 1v.

SOUZA, Miguel. A saída para o Pacifico. : [S. I. :s.n .], 1993. 1v.

UNIVERSIDADE FEDERAL DE MATO GROSSO. Corredor Oeste, saída para o Pacifico. Cuiabá: [s.n .], 1995. 1v.

Geografia Ensino \& Pesquisa, v. 15, n.3, p. 27-54 set./dez. 2011 
Geografia Ensino \& Pesquisa, v. 15, n.3, p. 27-54,

set./dez. 2011

Rota Pantanal Pacífico - a maior aventura das

Américas

$54 \quad$ |

ISSN 2236- 4994 